\title{
Analysis of natural product regulation of cannabinoid receptors in the treatment of human disease is
}

\author{
S. Badal ${ }^{\text {a,* }}$, K.N. Smith ${ }^{\text {b }}$, R. Rajnarayanan ${ }^{\text {c }}$ \\ a Department of Basic Medical Sciences, Faculty of Medical Sciences, University of the West Indies, Mona, Jamaica \\ ${ }^{\mathrm{b}}$ Department of Genetics, University of North Carolina at Chapel Hill, Chapel Hill, NC, USA \\ c Jacobs School of Medicine and Biomedical Sciences, Department of Pharmacology and Toxicology, University at Buffalo, Buffalo, NY 14228, USA
}

\section{A R T I C L E I N F O}

Available online 3 June 2017

Keywords:

Drug dependence/addiction

GTPases

G proteins

$G$ protein-coupled receptor

Natural products

Neurodegenerative disorders

\begin{abstract}
A B S T R A C T
The organized, tightly regulated signaling relays engaged by the cannabinoid receptors (CBs) and their ligands, $G$ proteins and other effectors, together constitute the endocannabinoid system (ECS). This system governs many biological functions including cell proliferation, regulation of ion transport and neuronal messaging. This review will firstly examine the physiology of the ECS, briefly discussing some anomalies in the relay of the ECS signaling as these are consequently linked to maladies of global concern including neurological disorders, cardiovascular disease and cancer. While endogenous ligands are crucial for dispatching messages through the ECS, there are also commonalities in binding affinities with copious exogenous ligands, both natural and synthetic. Therefore, this review provides a comparative analysis of both types of exogenous ligands with emphasis on natural products given their putative safer efficacy and the role of $\Delta 9$-tetrahydrocannabinol ( $\triangle 9$-THC) in uncovering the ECS. Efficacy is congruent to both types of compounds but noteworthy is the effect of a combination therapy to achieve efficacy without unideal side-effects. An example is Sativex that displayed promise in treating Huntington's disease (HD) in preclinical models allowing for its transition to current clinical investigation. Despite the in vitro and preclinical efficacy of $\triangle 9$-THC to treat neurodegenerative ailments, its psychotropic effects limit its clinical applicability to treating feeding disorders. We therefore propose further investigation of other compounds and their combinations such as the triterpene, $\alpha, \beta$-amyrin that exhibited greater binding affinity to $\mathrm{CB}_{1}$ than $\mathrm{CB}_{2}$ and was more potent than $\triangle 9$-THC and the $N$-alkylamides that exhibited $\mathrm{CB}_{2}$ selective affinity; the latter can be explored towards peripherally exclusive ECS modulation. The synthetic $\mathrm{CB}_{1}$ antagonist, Rimonabant was pulled from commercial markets for the treatment of diabetes, however its analogue SR144528 maybe an ideal lead molecule towards this end and HU-210 and Org27569 are also promising synthetic small molecules.
\end{abstract}

\section{Contents}

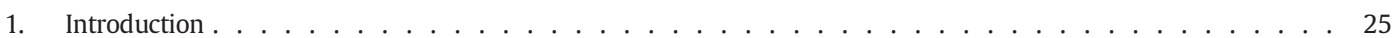

2. The physiology of the ECS . . . . . . . . . . . . . . . . . . . . . . . . . . . 25

3. ECS signaling gone awry and its restoration . . . . . . . . . . . . . . . . . . . . . . . . . 28

4. Concluding remarks and future perspectives $\ldots \ldots \ldots \ldots$

$5 . \quad$ Expert opinion by David Puett . . . . . . . . . . . . . . . . . . . . . . . . . . . . . . . . . . . . . . 42

Conflict of interest. . . . . . . . . . . . . . . . . . . . . . . . . . . . 42

Submission declaration . . . . . . . . . . . . . . . . . . . . . . . . . . . . . . . . . . . . . 42

Funding sources. . . . . . . . . . . . . . . . . . . . . . . . . . . . . . . . . . . . . . . . . . . . . .

\footnotetext{
Abbreviations: AC, adenyl cyclase; AD, Alzheimer's disease; 2-AG, 2-arachidonoylglycerol; ABHD6, $\alpha, \beta$ hydrolase 6; AEA, arachidonylethanolamide/anandamide; ALS, amyotrophic

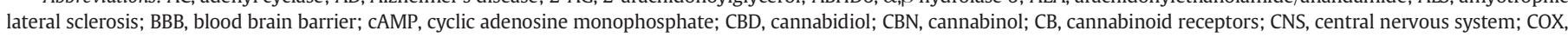

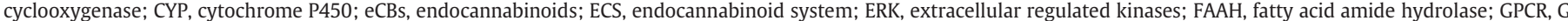

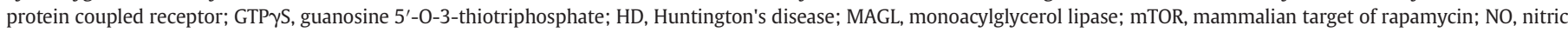

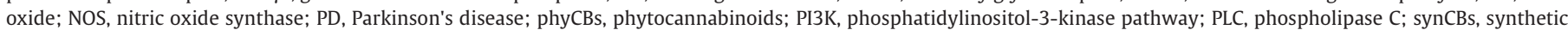
cannabinoids; THCV, tetrahydrocannabivarin; $\triangle 9$-THC, $\triangle$ 9-tetrahydrocannabinol.

is Associate editor: J. Hardwick.

* Corresponding author.

E-mail address: simone.badal@uwimona.edu.jm (S. Badal).
} 
Acknowledgments . . . . . . . . . . . . . . . . . . . . . . . . . . . . . . . . . . 42

References... . . . . . . . . . . . . . . . . . . . . . . . . . . . . 4 42

\section{Introduction}

The cannabinoid receptors (CBs), their ligands, machinery for ligand synthesis, metabolism, clearance and transport, along with $G$ proteins and other effectors, participate in numerous signal relays. Altogether, these participants are canopied by the endocannabinoid system (ECS), which is uniquely poised to maintain cellular homeostasis, providing an avenue for disease preclusion. Endocannobinoids (eCBs), ligands of the $\mathrm{CBs}$ are synthesized upon demand from membrane phospholipids (e.g. arachidonylethanolamide/anandamide (AEA) and 2-arachidonoylglycerol (2-AG); Cadas, di Tomaso, \& Piomelli, 1997; Di Marzo et al., 1994; Marrs et al., 2010; Muccioli, 2010; Schmid, Reddy, Natarajan, \& Schmid, 1983) in response to increases in intracellular $\mathrm{Ca}^{+}$followed by cellular uptake and rapid clearance. The two established $C B s$ are $C B_{1}$, which is highly expressed throughout the body and $\mathrm{CB}_{2}$, which is mainly localized in immune cells. Activation of presynaptic $\mathrm{CB}_{1}$ blocks neurotransmitter release through a mixed function response in which potassium channels are stimulated, while calcium channels are inhibited (Howlett et al., 2002). Stimulation of $\mathrm{CB}_{1}$ in extra-neuronal cells like the liver where immeasurable levels of $\mathrm{CB}_{1}$ exist, results in an elevated expression of acetyl-CoA carboxylase and fatty acid synthase (Osei-Hyiaman et al., 2005). Meanwhile, $\mathrm{CB}_{2}$ expression in immune cells participates in many immunosuppressive responses, such as inhibition of proinflammatory cytokine production (Maresz et al., 2007). The CBs, together with their associated targets within the ECS, function in copious signaling relays to modulate physiological and pathophysiological outcomes (appetite, respiration, metabolism, inflammation, pain, neurotransmission etc.) in different tissues. Therefore, dysregulation of these processes can effectuate acute or chronic diseases such as neurological and cardiovascular disorders, diabetes and cancers (Insel, Tang, Hahntow, \& Michel, 2007).

As such, modulators of this unique system have garnered significant attention (Novack, 2016; Reuter \& Martin, 2016; Sherman \& McRae-Clark, 2016; Zlebnik \& Cheer, 2016) in recent times. Furthermore, research on this system over the years have generated clinically applicable drugs (Cannabinor, Dexanabinol, Rimonabant, Sativex, Nabilone, and Dronabinol/Marinol), some of which have been withdrawn from commercial markets due to adverse effects. Despite these withdrawals, the promised efficacy of the ECS modulators continues to drive research towards regulatory approval of lead molecules, both natural and synthetic in origin.

Natural product research towards the development of drugs, also termed Pharmacognosy, dates back to the time of Hippocrates (470$350 \mathrm{BCE}$ ). It was the common practice then to use natural products, which at the time were primarily from plants, to achieve healing and also to protect against diseases (American Herbal Pharmacopoeia, 2013). As a result, the field of drug discovery developed from natural isolates. Moreover, $\triangle 9$-THC from the Cannabis sativa plant alluded to the eCBs, CBs and subsequently the ECS. Natural products continue to be ideal screening agents in the arena of drug development; indeed more than $50 \%$ of traditional drugs are either directly of natural origin or are templates of natural sources (Newman \& Cragg, 2012). Furthermore, $30-50 \%$ of traditional medicines are believed to act through $G$ protein coupled receptor proteins, of which $C B s$ are members (Bjenning, Al-Shamma, Thomsen, Leonard, \& Behan, 2004; Dahl \& Sylte, 2005; Doggrell, 2004; Kroeze, Sheffler, \& Roth, 2003). It is the belief of many that natural products do provide safer outcomes with less associated side-effects, however, research has shown that such notion tends to be more anecdotal than evidence based (Meier \& Lappas, 2015). The father of toxicology, Roman physician Paracelsus believed that all things are poisonous, with the distinction between safety and efficacy residing in the dose (Borzelleca, 2000). It is unclear whether or not there are safer effects attributable to natural products' use, however it is evident that their chemistry continue to provide clues towards the treatment of diseases especially through novel targets.

This review presents an overview of the ECS, factors that cause its dysregulation, the use of natural and synthetic products towards ECSassociated morbidities and future perspectives. The emphasis will be on natural products' modulation of the ECS and whether based on a comprehensive overview, they provide better alternatives.

\section{The physiology of the ECS}

\subsection{ECS signaling}

CBs belong to the rhodopsin type family within the GPCRs and while structural elucidations for the CBs are still ongoing, a review by Kenakin and Miller (2010) outlines the conformational changes experienced by this family of GPCRs upon ligand binding and the modulation of allosteric and orthosteric ligands to functionally identify novel drug leads. Within the rhodopsin family, three regions were postulated to participate in their activation, i) Trp6.50, at the bottom of the major intra-helical ligand-binding pocket, ii) Tyr7.53, postulated to unite the bottom of TM7 and helix 8 at the cytosolic surface of the lipid bilayer, and iii) Arg3.50 at the cytosolic locale of TM3, where it possibly couples with the $G$ protein. Together, these regions are believed to manipulate the rhodopsin type GPCRs' response to ligand binding and their conformational change to the cytosolic interface that aid or thwart coupling to specific effectors in order to transduce intracellular signaling.

A common feature of the GPCR signaling pathway is initiation by a ligand (hormones, neurotransmitters, inflammatory mediators and other bioactive molecules) that binds to a GPCR protein (Cabrera-Vera et al., 2003). Ligand-mediated activation of the GPCR in turn stimulates $G$ proteins that are comprised of three subunits: $\alpha, \beta$ and $\gamma$ and such stimulation prompts the replacement of GDP with GTP in the G $\alpha$ subunit as shown in Fig. 1. The $\mathrm{G}_{\alpha}$-GTP complex is then dissociated from the $\mathrm{G}_{\beta \gamma}$ subunits, an action that enables both molecular entities to transduce numerous signals through their various effectors (Cabrera-Vera et al., 2003) as shown in Fig. 2. In addition, $\mathrm{CB}_{1}$ or $\mathrm{CB}_{2}$ ligand signal transductions are also achieved through $\beta$-arrestin couplings that have been shown to participate in receptor desensitization internalization, resensitization, and down-regulation (Daigle, Kearn, \& Mackie, 2008; Jin et al., 1999; Nguyen et al., 2012; Raehal \& Bohn, 2014; Sim, Hampson, Deadwyler, \& Childers, 1996).

GPCRs are usually named after their ligands and so this section will examine the signaling cascade involved in message relay initiated by the cannabinoid/CB pockets. The CB itself is coined after the plant, Cannabis sativa that led to its discovery (Di Marzo \& Maccarrone, 2008). The structural identification of the plant's principal ingredient $\triangle 9$-THC (Gaoni \& Mechoulam, 1964) and subsequently the bioactivity of its $l$ stereoisomer (Mechoulam, Braun, \& Gaoni, 1967) together acted as a springboard for identifying to date 113 cannabinoids in the Cannabis sativa plant (Aizpurua-Olaizola et al., 2016), including eCBs and endogenous arachidonic acid derivatives, in addition to the synthesis of approximately $180 \Delta 9$-THC analogues (Banister et al., 2015; Howlett et al., 2002; Rosati et al., 2014). Therefore, the rhodopsin CBs are regulated by three categories of ligands, eCBs, phytocannabinoids (phyCBs) and synthetic cannabinoids (synCBs). PhyCBs are referred to here as any natural product from the Cannabis sativa or other plants that either directly (modulate $\mathrm{CBs}, \mathrm{G}$ proteins, eCBs or $\beta$-arrestins) or indirectly 


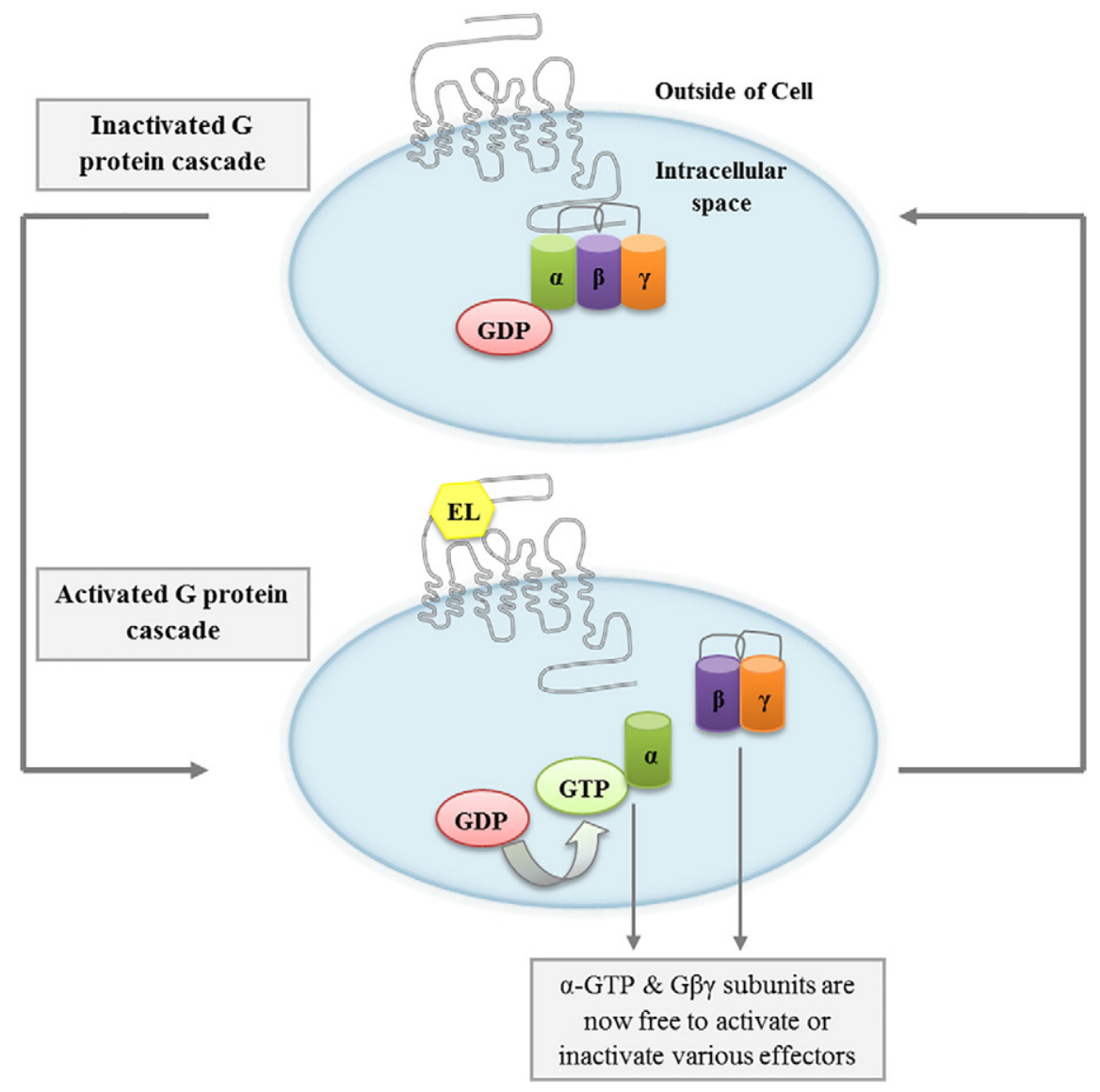

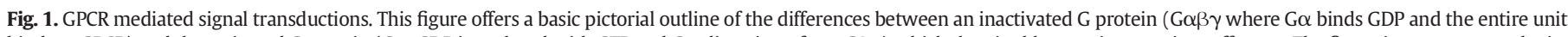

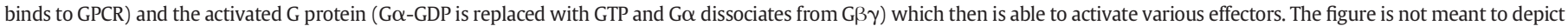
appropriate ratios of the proteins to the cell itself. Key: EL-endogenous ligand.

(modulate the enzymatic systems that synthesize, metabolize, transport and clear the eCBs including fatty acid amide hydrolase (FAAH), monoacylglycerol lipase (MAGL), diacylglycerol lipase (DAGL) $\alpha, \beta$ hydrolase 6 and 12 (ABHD6 and ABHD12)) interact with the ECS and/or share chemical similarity with the eCBs.

There are to date, two main identified types of $\mathrm{CBs}, \mathrm{CB}_{1}$ that is primarily localized in the brain (although it is also found in lungs, liver and kidneys) and $\mathrm{CB}_{2}$ that is mostly expressed in peripheral tissues, in particular, the immune and skeletal systems (Ameri, 1999). Very recent $\mathrm{X}$-ray crystal structures (Fig. 3 shows identified amino acid residues that function in $\mathrm{CB}_{1}$ 's regulation) have become available for $\mathrm{CB}_{1}$ (Hua et al., 2016; Shao et al., 2016) after considerable attempts at preparing CB homology models (Feng et al., 2014; Liu, Patel, \& Doerksen, 2014; Shim, Welsh, \& Howlett, 2003). Both CBs couple to the $G$ protein effector, $G_{\text {io }}$ and their signal transductions are complex and only summarized here where the following observations are not necessarily similar in all tissues expressing $\mathrm{CBs}$. $\mathrm{CB}_{1}$ couples to $\mathrm{Gs} \mathrm{G}$ proteins although $\mathrm{G}_{\mathrm{i}}$ coupling is the canonical coupling for $\mathrm{CB}_{1}$. More comprehensive reviews on the ECS signaling cascade (Dalton, Bass, Van Horn, \& Howlett, 2009; Howlett and Shim, 2000-2013; Howlett et al., 2004; Maccarrone et al., 2015 ) exist for consultation. Ligand induced $\mathrm{CBs} / \mathrm{G}_{\text {io }}$ associations typically result in inhibition of the cyclase activity of AC usually the AC 1 , 3, 5, 6 and 8 isoforms, while CBs/G $\beta \gamma$ associations activate AC 2, 4 and 7 isoforms (Rhee, Bayewitch, Avidor-Reiss, Levy, \& Vogel, 1998). Receptor dimerization has also been observed to participate in AC activation when GPCR dopamine $\mathrm{D}_{2}$ and $\mathrm{CB}_{1}$ are simultaneously activated (Glass \& Felder, 1997; Kearn, Blake-Palmer, Daniel, Mackie, \& Glass, 2005). This dimerization has also been linked to $\mathrm{CB}_{1} / \mathrm{G} \alpha$ coupling while $\mathrm{CB}_{1}$ / $\mathrm{G}_{\mathrm{q} / 11}$ coupling leads to an increase in intracellular calcium ions (Lauckner, Hille, \& Mackie, 2005) and Phospholipase C (PLC) activation
(Piiper, Stryjek-Kaminska, Klengel, \& Zeuzem, 1997). Meanwhile, $\mathrm{CB}_{1} /$ $\mathrm{G}_{\beta \gamma}$ coupling modulates phosphorylation of different ion channels, as calcium channels are inhibited (Gebremedhin, Lange, Campbell, Hillard, \& Harder, 1999; Mackie \& Hille, 1992) whereas potassium channels are activated (Mackie, Lai, Westenbroek, \& Mitchell, 1995). $C_{1} / G_{i \alpha}$ coupling also participates in the phosphorylation of ion channels, however, this is mediated through inhibiting $A C(1,3,5,6$, and 8 isoforms), an outcome that stimulates protein kinase $A$. In addition, $C B_{1} / G_{\text {io }}$ coupling i) induces all three families of multifunctional mitogen-activated protein kinases, including p44/42 (Davis, Ronesi, \& Lovinger, 2003; Wartmann, Campbell, Subramanian, Burstein, \& Davis, 1995), p38 kinase (Derkinderen, Ledent, Parmentier, \& Girault, 2001; Liu et al., 2000), and JUN-terminal kinase (Liu et al., 2000; Rueda, Galve-Roperh, Haro, \& Guzman, 2000); ii) activates the phosphatidylinositol-3-kinase (PI3K) and MAPK pathways directly (Gomez Del Pulgar, De Ceballos, Guzman, \& Velasco, 2002) and independently (Asimaki \& Mangoura, 2011) and iii) activates calcineurin (Stefano et al., 1997). The $\mathrm{CB}_{1} / \mathrm{G}$ protein coupling specificities remain to be fully elucidated with regards to NOS stimulation as information is steered to $\mathrm{CB}_{1} /$ ligand coupling (Stefano et al., 1997). More recently, $\mathrm{CB}_{1}$ was shown to activate extracellular regulated kinases also known as ERK1/2 and neuronal induction in primary neurons from chick embryo telencephalon through lipid rafts (Asimaki \& Mangoura, 2011).

Unlike $\mathrm{CB}_{1}$, the elucidation of many signal transduction pathways for $C B_{2}$ are yet to be discovered. Current $C_{2}$ mediated effects include $C B_{2} /$ $\mathrm{G}_{\mathrm{i} / \mathrm{o}}$ trafficking that participates in the inhibition of cAMP (Rhee et al., 1998) and the activation of MAPK, p42/44 family (Bouaboula et al., 1996). However, $C_{2}$ agonists failed to activate PKB/Akt in HL60 cells, suggesting that a $\mathrm{PI} 3 \mathrm{~K}$ mechanism may not be engaged by $\mathrm{CB}_{2}$ receptors (Gomez Del Pulgar et al., 2002). In contrast, the expression of the 


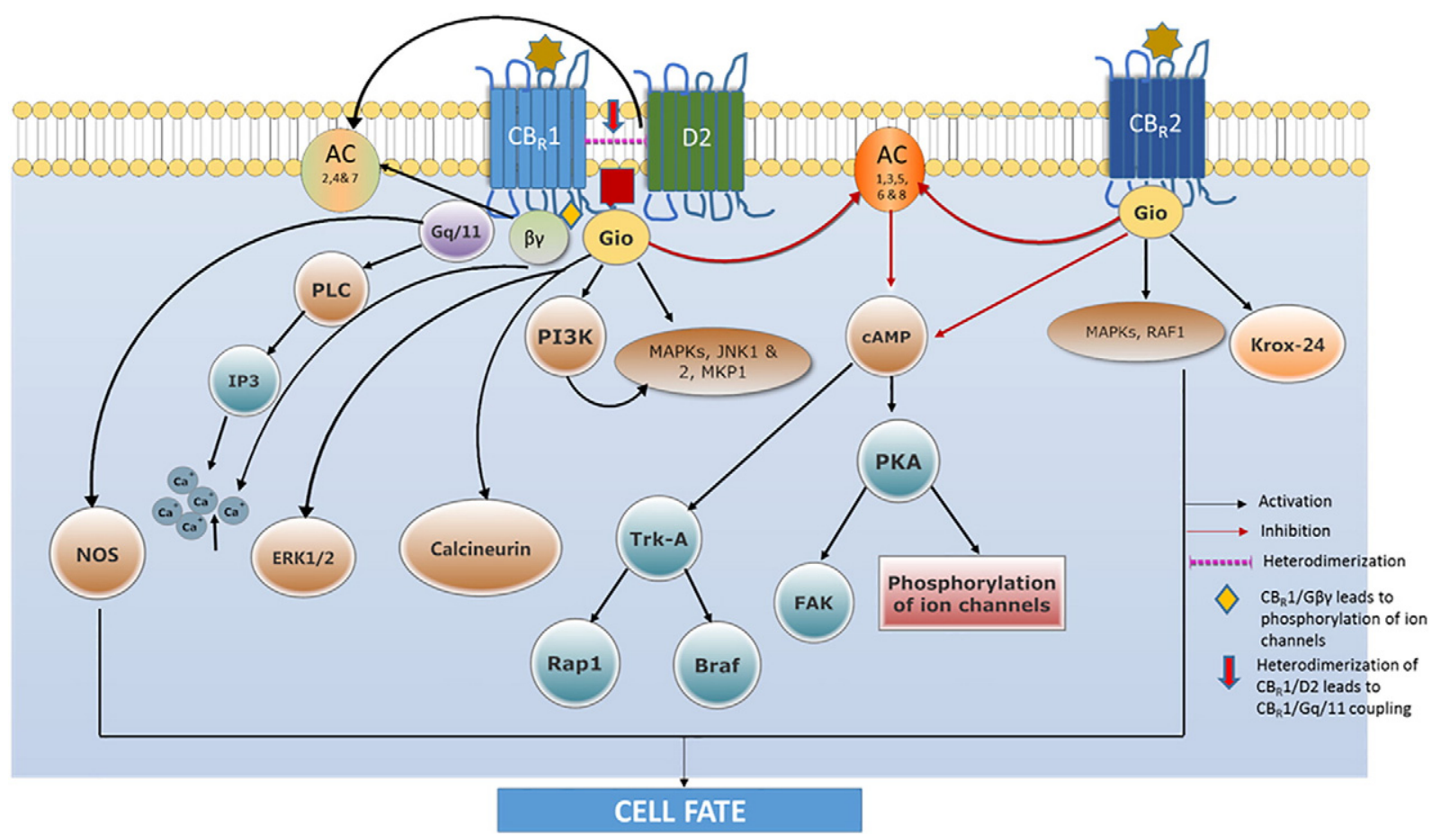

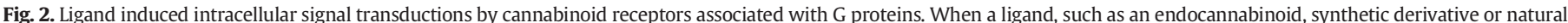

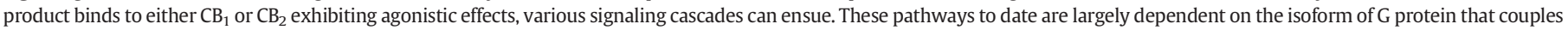

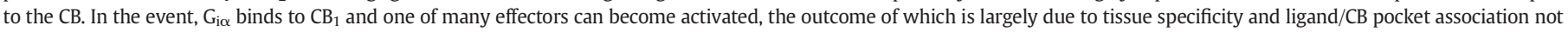

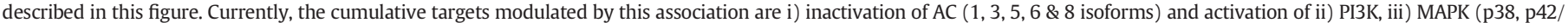

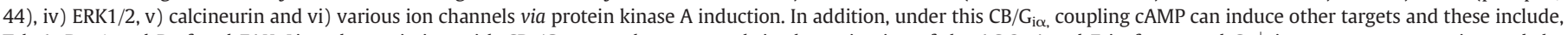

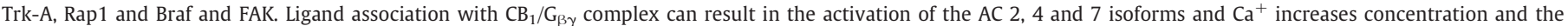

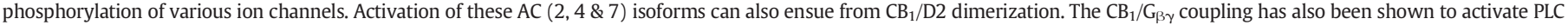

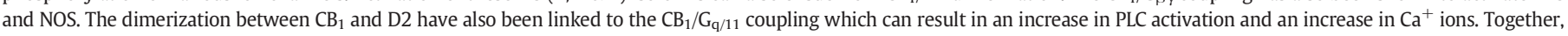


protein independent signaling such as the activation of p42/44MAPK cascade or Src kinases in addition to CB desensitization and internalization.

nuclear protein that functions as a transcriptional regulator, Krox-24 also known as EGR-1 (early growth response protein 1) was stimulated by $\mathrm{CB}_{2}$ receptors in HL60 promyelocytes (Bouaboula et al., 1996).

\subsection{Endocannabinoids, cues for cannabinoid modulation}

Documentation of $\triangle 9$-THC as a ligand of the CBs paved the way for identifying eCBs and elucidating their mechanisms of action. The varied binding modalities by these eCBs as either orthosteric (primary unmodulated) agonists, inverse agonists or antagonists contribute to ECS mediated physiological outcomes. The first eCB, anandamide, also referred to as $\mathrm{N}$-arachidonoylethanolamine or AEA was discovered in 1992 by Devane et al. (1992). This discovery was made only a year after the elucidation of $\mathrm{CB}_{1}$ (Matsuda, Lolait, Brownstein, Young, \& Bonner, 1990) and before the elucidation of $\mathrm{CB}_{2}$ (Munro, Thomas, \& Abu-Shaar, 1993). The second eCB, 2-AG, was discovered three years later (Mechoulam et al., 1995; Sugiura et al., 1995). Since then, other putative eCB targets have been identified (Johns et al., 2007; Overton et al., 2006) but the biosynthesis, metabolism, transport and function of eCBs have been primarily focused on AEA and 2-AG.

The production of these eCBs occurs when there is an elevation in intracellular $\mathrm{Ca}^{2+}$ subsequent to either neuron depolarization or activation of metabotropic $G_{q / 11}$-coupled receptors. AEA is a fatty acid derivative neurotransmitter that is synthesized from $\mathrm{N}$-arachidonoyl phosphatidylethanolamine by many pathways, derived from the nonoxidative metabolism of arachidonic acid (Cadas et al., 1997; Di Marzo et al., 1994; Schmid et al., 1983) and discussed in more detail in Bosier, Muccioli, Hermans, \& Lambert (2010), Pacher, Batkai, \& Kunos (2006), and Pertwee (2009). In contrast, 2-AG is produced from activities of diacylglycerol lipase (DAGL) and PLC and different pathways are engaged in its in vitro versus in vivo synthesis (Savinainen, Saario, \& Laitinen, 2012). Once taken up into the cell, AEA's metabolism is achieved by FAAH while MAGL is primarily observed to catalyze 2-AG although ABHD6 (Marrs et al., 2010), ABHD12 and FAAH (Blankman, Simon, \& Cravatt, 2007) also participate in the hydrolysis of 2-AG. The inducible form of COX, COX2 also plays a role in oxidizing AEA and 2AG (Kozak et al., 2002).

Both eCBs are agonists of $\mathrm{CB}_{1}$ and $\mathrm{CB}_{2}$ receptors, however, $\mathrm{AEA}$ exhibits low $\mathrm{CB}_{1}$ efficacy and an even lower efficacy towards $\mathrm{CB}_{2}$. Meanwhile, 2-AG binds to the $\mathrm{CBs}$ with reduced affinity but is fully effective at both CBs (Gonsiorek et al., 2000). The eCBs are released upon demand, bind to the coupled $\mathrm{CB} / \mathrm{G}$ protein complex inducing signaling cascades as observed in Fig. 2, prior to being rapidly cleared from the extracellular matrix. Their transport mechanism however remains to be fully unraveled although a putative eCB transporter and heat shock proteins (Hsp70s) are implicated in AEA transport (Gerdeman, Ronesi, \& Lovinger, 2002; Maccarrone et al., 2000), while fatty acid binding proteins are implicated in the transport of both eCBs (Kaczocha, Glaser, \& Deutsch, 2009; Oddi et al., 2009).

In the $\mathrm{CNS}$, signaling of the $\mathrm{eCB} / \mathrm{CB}_{1} / \mathrm{G}$ protein complex is to date largely achieved using retrograde synaptic relay (Chevaleyre, Takahashi, \& Castillo, 2006; Wilson \& Nicoll, 2002). As retrograde messengers, eCBs are released from depolarized postsynaptic neurons in a calcium-dependent manner as they reversely inhibit periglomerular cells by way of glutamatergic neurons that are presynaptic to these cells. Therefore, retrograde signaling induced inhibition of the periglomerular cells controls the cell's GABA release, which in turn controls primary cell activity (Thomas, Ze-Jun, Edward, \& Paul, 2016). Findings show that retrograde signaling by the eCBs may be important for treating feeding disorders (Pertwee, 2006b) as elucidations indicate 
that some mechanisms are involved in $\mathrm{CB}_{1}$ 's participation in increasing food intake in mice via elevating odor detection. These include a reduction in the excitatory drive of the olfactory cortex areas in the main olfactory bulb (Soria-Gomez, Bellocchio, \& Marsicano, 2014). Further, it is believed that the eCBs' involvement in the inhibition of periglomerular cells provides novel insights into their potential role to mitigate substance abuse (Thomas et al., 2016). Endocannabinoids also participate in regulating cell migration and the production of cytokines and chemokines which play a role in maintaining homeostatic immune function (Cabral, Ferreira, \& Jamerson, 2015). Conversely, elevated levels of the eCB, AEA, have been associated with stunted embryonic development, foetal loss and pregnancy failure (Maccarrone, 2009; Maccarrone et al., 2001). Altogether, supporting evidence exists which underlies eCBs as neuromodulators and immunomodulators and their inhibition towards enhanced fertility. These translate to antinociceptive action (Kaczocha et al., 2014), anxiolytic-like properties (Marco et al., 2015), antidepressant activity (Trezza \& Campolongo, 2013), anti-tumour efficacy (Picardi, Ciaglia, Proto, \& Pisanti, 2014), and the lowering of blood pressure in hypertensive experimental models (Batkai, Pacher, Jarai, Wagner, \& Kunos, 2004). The continuous elucidation of the pharmacological properties of the eCBs underscores their value in restoring cellular homeostasis and treating certain diseases while taking into account their adverse effects.

\section{ECS signaling gone awry and its restoration}

\subsection{Factors that affect ECS and its signaling relay}

Di Marzo, Stella, and Zimmer (2015) discuss at length in a review, factors that are associated with a dysregulated ECS highlighting age, neurological diseases and cancer and so will only be briefly mentioned here in addition to mutations within the CBs caused by genetic or epigenetic factors (Gyombolai, Toth, Timar, Turu, \& Hunyady, 2015).

Clinical and pre-clinical evidence exist that demonstrate the impact ageing has on varied aspects of the ECS signal relay. Firstly, a reduction in $\mathrm{CB}_{1}$ gene expression levels was observed in the extrapyramidal structures of aged rats compared to their younger counterparts (Berrendero et al., 1998; Rodriguez de Fonseca, Ramos, Bonnin, \& Fernandez-Ruiz, 1993). Furthermore, the $\mathrm{CB}_{1}$ binding affinity was also impacted in these preclinical models and other research confirms this effect in a clinical setting (Rodriguez de Fonseca et al., 1993). In humans, the expression of key genes in the ECS that regulate CB's orthosteric ligands and their inactivating enzymes were impacted with maturation of brain function (Long, Lind, Webster, \& Weickert, 2012). CB/G protein coupling was also affected by ageing in the limbic forebrain of mouse models (Wang, Liu, Harvey-White, Zimmer, \& Kunos, 2003).

Classical (e.g. Alzheimer's disease (AD), Parkinson's disease (PD) and amyotrophiclateral sclerosis (ALS)) or inflammatory associated (e.g. multiple sclerosis (MS) and HIV-associated dementia) degenerative disorders of the CNS which may occur concomitantly with or independently of ageing (Stella, 2010) exhibit similar etiologies, neuroinflammation, excitotoxicity, deregulation of intercellular communication, mitochondrial dysfunction and disruption of brain tissue homeostasis. Induced signaling by $\mathrm{CB}_{1}$ and $\mathrm{CB}_{2}$ are important to $\mathrm{Ca}^{2+}$ homeostasis, trophic support, mitochondrial activity (Ranieri, Laezza, Bifulco, Marasco, \& Malfitano, 2016), the generation, specification and maturation of neurons in addition to brain maturation (Skaper \& Walsh, 1998). Preclinical evidence supports an association between inflammation and ECS derived neurological disease (Hegde, Nagarkatti, \& Nagarkatti, 2010) in mice that underwent experimental allergic encephalomyelitis (EAE) or multiple sclerosis. Other findings (Maresz et al., 2007) demonstrated the role of low levels of $\mathrm{CB}_{2}$ in non-CNS cells to prevent and control neuroinflammation and its accompanied disorders. Consequently, disrupted $\mathrm{CB}_{1 / 2}$ signaling may play a role in degenerative disorders of the CNS.
The mammalian target of Rapamycin (mTOR) is a target molecule associated with cancer and it is one of the downstream signaling effectors of $\mathrm{CB}_{1}$ and leptin through PI3K activation. mTOR enables both cellular nutrient sensing and energy homeostasis through the ERK/MAPKAkt pathway, in addition to the expression of c-myc and cyclin D1 that contributes to cell growth and survival and the transcription of a number of hypoxia-inducible genes including vascular endothelial growth factor (VEGF) and platelet derived growth factor (PDGF) (Rini \& Atkins, 2009). These genes have implications for mitogenesis, permeability, vascular tone and the production of vasoactive molecules (Zachary, 1998). Therefore, the mTOR complex participates in a wide array of biological functions including angiogenesis, synaptic plasticity and cognitive function, and usage of the MTOR inhibitor, Rapamycin, blocked mTOR mediated angiogenesis (Sekiguchi et al., 2012) and conferred cellular cytoprotectivity (Busquets-Garcia et al., 2013; Rubinsztein, Marino, \& Kroemer, 2011). Interestingly, antagonism of $\mathrm{CB}_{1}$ was shown to inhibit autophagy in a mTOR mediated manner (Hiebel, Kromm, Stark, \& Behl, 2014), a phenomenon possibly related to ageing and certain neurodegenerative disorders such as ALS and PD (Centonze, Finazzi-Agro, Bernardi, \& Maccarrone, 2007).

Finally, CB mutations have been associated with anomalies in the ECS signal relay that are concomitant to certain diseases like certain neurodegenerative disorders, discussed more by Maccarrone, Bernardi, Agrò, \& Centonze (2011). The review highlights the general role cholesterol plays with respect to the $\mathrm{CBs}$ which can either be through a direct impact of the $\mathrm{CB}$ conformation states via CRAC, cholesterol recognition amino acid sequence consensus in helix 7 on the CBs or indirectly altering the physiochemical properties of the bilayer as shown in Fig. 3. More definitive mutations such as single-, double- and/or triple-alanine mutations in the highly conserved DRY motif within the $\mathrm{CB}_{1}$ have been recently found to display either bias towards $G$ proteins or $\beta$-arrestins (Gyombolai et al., 2015). Single alanine mutations decreased $G_{o}$ protein activation and enhanced basal $\beta$-arrestin 2 recruitment while a double mutant $\left(\mathrm{CB}_{1}\right.$-D3.49A/R3.50A) augmented $\beta$-arrestin 1 and 2 recruitment but decreased $\mathrm{G}$-protein activation. $\mathrm{CB}_{2}$ mutations have been linked to oncogenic effects as $C B_{2}$ gene transforming mechanisms using ligands or retroviral insertions resulted in altered cellular migration and a reduction in neutrophilic development in addition to aberrant expression of $\mathrm{CB}_{2}$ in human myeloid cell lines respectively (Alberich Jorda et al., 2004).

\subsection{Synthetic CB ligands}

The identification of the natural isolate, $\Delta 9$-THC from the Cannabis sativa plant not only led to the identification and isolation of other naturally derived phyCBs (natural products from the Cannabis sativa or other plants that modulate the ECS) but to synCBs, synthetic products that also modulate the ECS. These synCBs are structurally classified as either classical, non-classical, aminoalkylindoles, eicosanoids or others and are represented in Table 1. Classical ligands are analogues of the $\triangle 9$-THC isolate and these tend to behave as agonists of the CBs showing minimal selectivity but in some cases showing increased affinity. One such example is HU-210 whose increased affinity to the $\mathrm{CB}$ is believed to be a result of replacing the pentyl side chain on $\triangle 9$-THC with a dimethylheptyl group (Griffin et al., 1997; Ross et al., 1999; Sanchez et al., 2001). HU-210 was shown to participate in maximal $C_{1}$ coupling to the $G$ proteins, $G_{i}$ and $G_{0}$ compared to the eCB, $A E A$ and the phyCB, $\triangle 9$-THC in addition to $\mathrm{CB}_{1}$ receptor-catalyzed activation of $\mathrm{G}_{\mathrm{i}}$ (Glass \& Felder, 1997). Moreover, activation of the $\mathrm{G}_{\mathrm{i} / \mathrm{o}}$ complex achieved by a synthetic peptide fragment from the juxtamembrane $\mathrm{C}$-terminal region of the $\mathrm{CB}_{1}$ receptor independently activated both [35S] guanosine 5'-O(3-thio)triphosphate (GTP $\gamma S$ ) binding to $G$ proteins and inhibition of adenylate cyclase (Howlett, Song, Berglund, Wilken, \& Pigg, 1998; Mukhopadhyay, Cowsik, Lynn, Welsh, \& Howlett, 1999), therefore indicating the role this domain plays in $\mathrm{G}_{\mathrm{i} / \mathrm{o}}$ activation. 


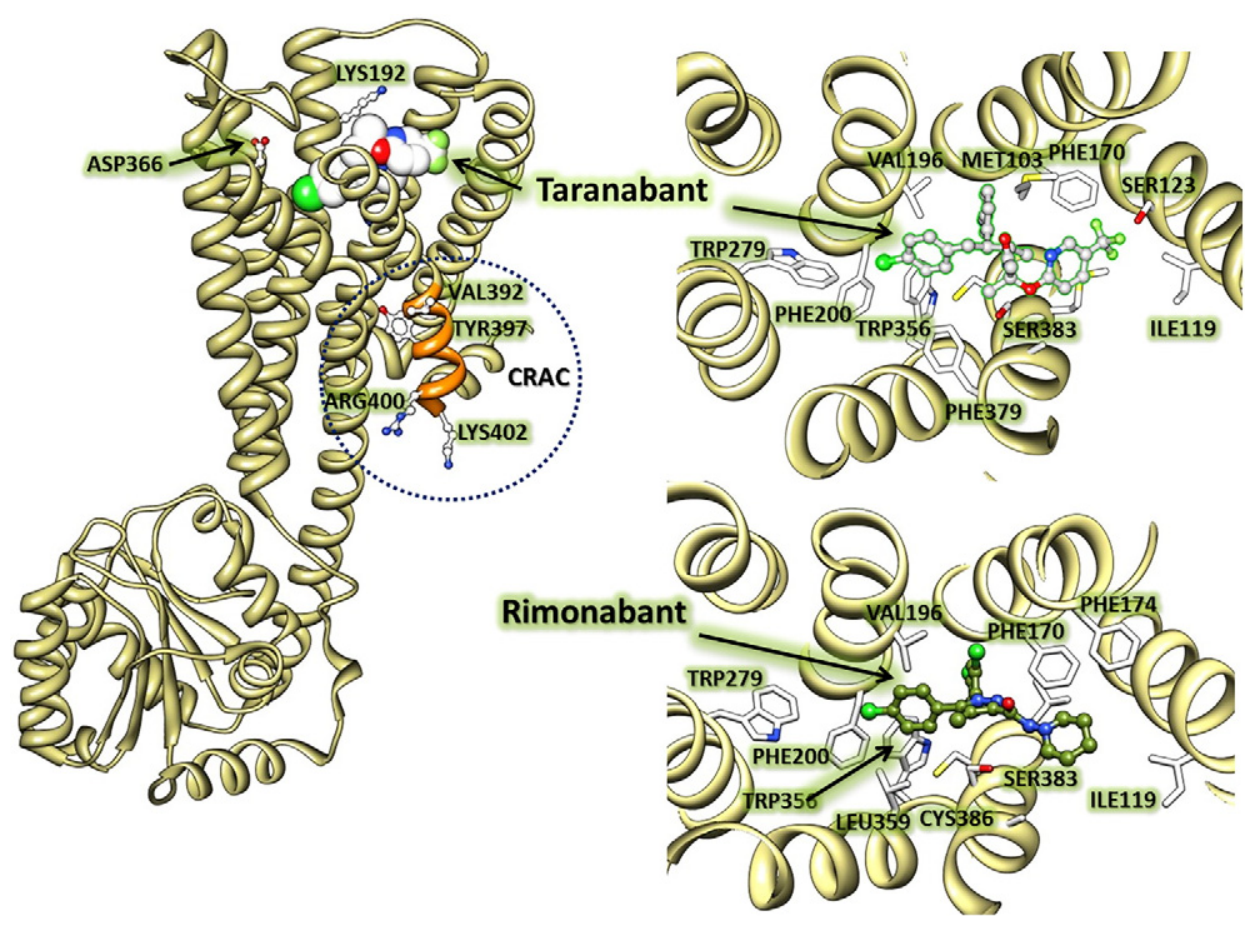

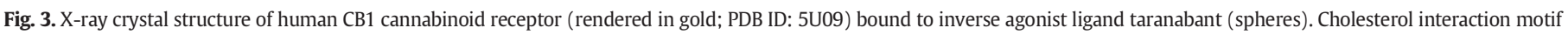

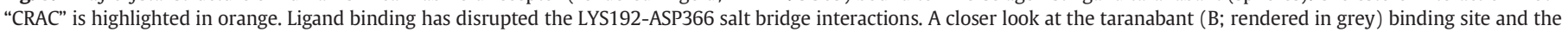
top docked pose of the inverse agonist ligand Rimonabant (C; rendered in olive green) reveal similar ring stacking interactions with PHE200/TRP356 and PHE170.

A characteristic of non-classical CB ligands is an A-ring accompanied by an aryl C-3 side chain bicyclic structure also termed, AC bicyclic and ACD-tricyclic structures that have an opening in the $\mathrm{D}$ rings. The $\mathrm{CB}$ bicyclic analog, CP55940, is a CB full agonist that is 45 times more potent than $\triangle 9$-THC, has parallel affinity for both $\mathrm{CB}_{1}$ and $\mathrm{CB}_{2}$ receptors and is highly potent in vivo (Rinaldi-Carmona et al., 1996). In 2005, the first $\mathrm{CB}_{1}$ allosteric site was identified (Price et al., 2005) and a synthetic compound, Org27569 was shown to enhance CB agonist binding (specifically CP55940), inhibit G protein-dependent agonist signaling using in vitro models expressing $\mathrm{CB}_{1}$ receptor (Ahn, Mahmoud, \& Kendall, 2012) and participate in $\beta$-arrestin $C_{1}$ biased signaling ( $A h n$, Mahmoud, Shim, \& Kendall, 2013). Org27569 demonstrated preclinical hypophagic activity that has implications for weight loss (Ding et al., 2014) and propelled the synthesis of other allosteric compounds with parallel binding affinities (Qiao et al., 2016). Allosteric modulation welcomes a novel approach to the manipulation of the ECS for therapeutic benefit. Recent research identified R- $(+)$-WIN55212, an aminoalkylindole that has a high affinity for both CBs with a slightly enhanced affinity for $\mathrm{CB}_{2}$, a property also displayed by the other aminoalkylindoles, JWH-015 and L-768242 (Showalter, Compton, Martin, \& Abood, 1996). R-(+)-WIN55212 also maximally activates $\mathrm{CB}_{1}$ receptor-catalyzed activation of $\mathrm{G}_{\mathrm{i}}$, while sub-maximally (at around $70 \%$ ) engages in $\mathrm{CB}_{1}$ stimulation of $\mathrm{G}_{0}$ (Glass \& Northup, 1999). Methylation of AEA results in methanandamide being 9fold more specific than $A E A$ for $\mathrm{CB}_{1}$ (Showalter et al., 1996). Overall, agonists of the $\mathrm{CBs}$ are involved in cognition, memory, anxiety, control of appetite, emesis, motor behavior, sensory, autonomic and neuroendocrine responses, immune responses and inflammatory effects (Svíženská, Dubový, \& Šulcová, 2008), liver injury and hepatocellular carcinoma (Sathyapalan et al., 2016) and so the reverse conditions are anticipated in the presence of their antagonists and these are highlighted in Fig. $4 . \mathrm{CB}_{1}$ 's primary locale in the hypothalamus underscores its potential value in treating feeding disorders since the hypothalamus plays a role in feeding regulation and is connected to the mesolimbic dopamine pathway, the so called 'reward' system.
Antagonists of the $\mathrm{CB}_{1}$ receptors are therefore believed to be important to the weight loss paradigm (Black, 2004) and drug (nicotine and $\triangle 9$-THC) cessation is important to weight gain (Filozof, Fernandez Pinilla, \& Fernandez-Cruz, 2004; Schindler et al., 2016). After a decade of attempts to synthesize the first $\mathrm{CB}$ antagonist, first through isoforms of $\Delta 9$-THC, Rinaldi-Carmona et al. (1994) reported the successful synthesis of SR141716A also called Rimonabant, a potent $\mathrm{CB}_{1}$ antagonist, that propelled the synthesis of other $\mathrm{CB}$ antagonists. Analogues of Rimonabant, $\mathrm{AM} 251$ and $\mathrm{AM} 281$ also block $\mathrm{CB}_{1}$ receptor-mediated effects while SR144528 is a $\mathrm{CB}_{2}$ antagonist (Rinaldi-Carmona et al., 1994, 1998). CBs active states can be induced by their respective ligands or by spontaneous shifting between inactive to active states (OrtegaGutierrez \& Lopez-Rodriguez, 2005). Rimonabant, the inverse agonist, binds to the $\mathrm{CB}_{1}$ and interaction is thought to exist through hydrogen bonding between the carbonyl group of Rimonabant and the Lys192 residue of the $\mathrm{CB}_{1}$ receptor, shown in Fig. 3. This bond stabilizes the Lys192-Asp366 salt bridge in $\mathrm{CB}_{1}$ helices 3 and 6 , believed to be specific to the inactive $\mathrm{CB}_{1}$ state (Lange \& Kruse, 2005; McAllister et al., 2003). Rimonabant, through direct stacking of its 2,4-dichlorophenyl ring to the Trp279/Phe200/Trp356 residues (on $\mathrm{CB}_{1}$ ) on one end and the para-chlorophenyl ring (on Rimonabant) to the Tyr275/Trp255/ Phe278 (on $\mathrm{CB}_{1}$ ) on the other end, binds within the transmembrane3-4-5-6 aromatic microdomain of the $\mathrm{CB}_{1}$ (Fan et al., 2009; Lange \& Kruse, 2005). These binding interactions with $\mathrm{CB}_{1}$ seem to be important to Rimonabant's clinical efficacy to treat diabetes (Muccioli \& Lambert, 2005) and a proposed mechanism is through increased insulin sensitivity in an age-dependent manner (Lipina et al., 2016) and oxidation of fatty acids in muscles and the liver (Patel \& Pathak, 2007). Current preclinical and in vitro findings suggest that Rimonabant through its $\mathrm{CB}_{1}$ antagonism treats non-alcoholic fatty liver disease (NAFLD) by blocking fatty liver metabolism (Sathyapalan et al., 2016). More recently, the effects of Rimonabant to minimize drug dependence of nicotine and $\Delta 9$ THC in squirrel monkeys were mimicked by a neutral antagonist, AM4113 (Schindler et al., 2016). Rimonabant as an antagonist/inverse agonist of the $\mathrm{CB}_{1}$ is much concretized and its implications in weight loss, anti-diabetes and reduced drug dependency are established. Also 
Table 1

Synthetic CB ligands, their structures, binding affinities and bioactivities.

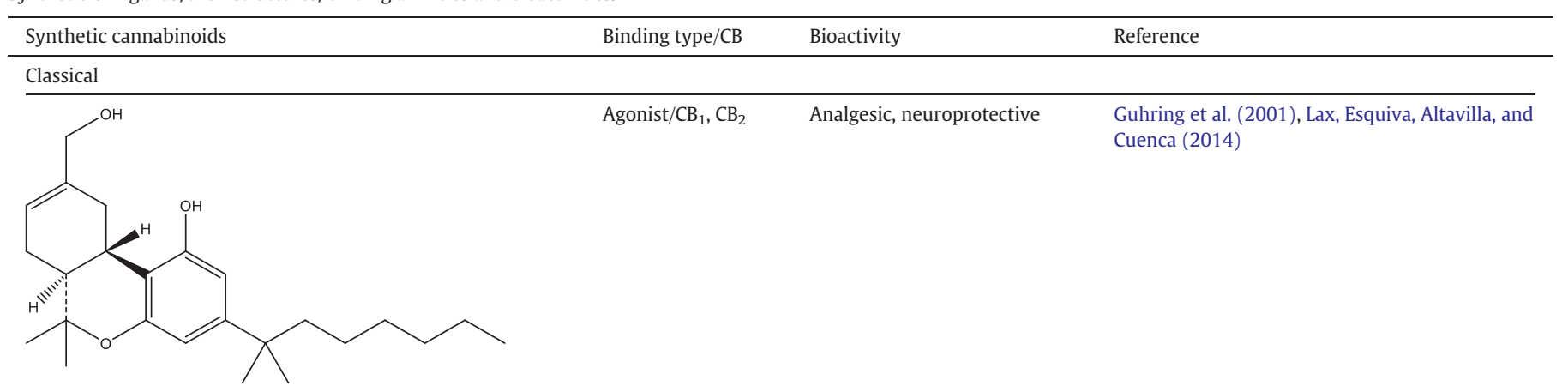

HU-210<smiles>CCCCCCC(C)(C)c1cc(O)c2c(c1)OC(C)(C)[C@@H]1CCC(=O)C[C@H]21</smiles>

Agonist $/ \mathrm{CB}_{1}, \mathrm{CB}_{2} \quad$ Analgesic, antiemetic, anti-inflammatory

Antiemetic, orexigenic

Agonist $/ \mathrm{CB}_{1}, \mathrm{CB}_{2}$<smiles>CCCCCc1cc(O)c2c(c1)OC(C)(C)[C@@H]1CC=C(C)C[C@H]21</smiles>

$\triangle 8-\mathrm{THC}$<smiles>CC1Nc2cc(O[C@@H](C)CCCc3ccccc3)cc(O)c2[C@H]2CC(O)CC[C@@H]12</smiles>

Desacetyl-L-nantradol<smiles>CCCC(C)(C)c1ccc2c(c1)OC(C)(C)[C@H]1CC=C(C)C[C@H]21</smiles>

Conti, Costa, Colleoni, Parolaro, and Giagnoni (2002), Darmani, Janoyan, Crim, and Ramirez (2007)

Avraham et al. (2004), Webster and Sarna (2007)

Pertwee (2005)

JWH-133 
<smiles>CCC(C)(C)c1ccc2c(c1)OC(C)(C)[C@H]1CC=C(C)C[C@H]21</smiles>

JWH-139

HO

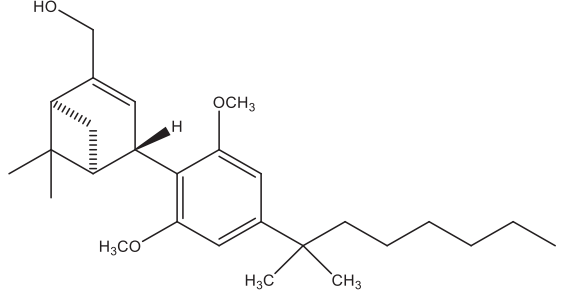

HU-308

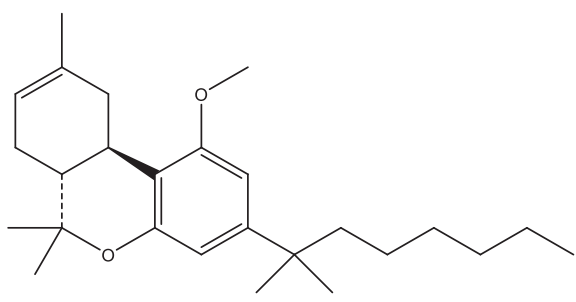

L-759633

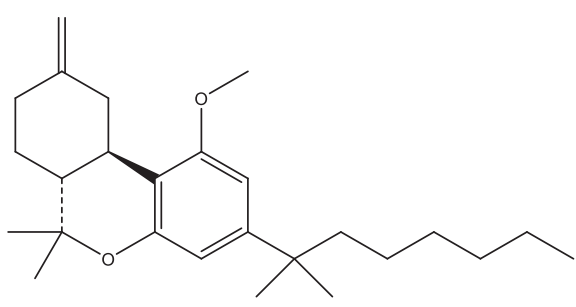

Agonist $/ \mathrm{CB}_{2}$

Analgesic

Analgesic, anti-inflammatory, lowers blood pressure

Agonist $/ \mathrm{CB}_{2}$

Analgesic

Ross et al. (1999)

Hanuš et al. (1999)

(19)

L-759656

Non-classical

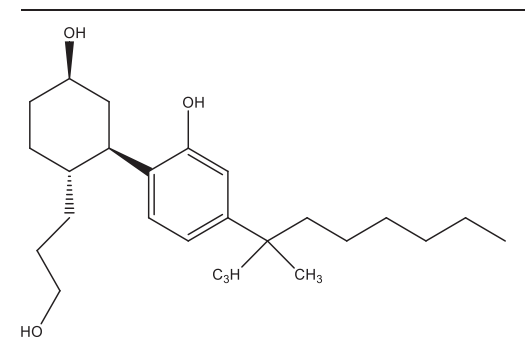

Agonist/non-selective Anti-nociceptive, antiemetic,

Darmani et al. (2003), Pugh, Mason, Combs, and Welch (1997)

CP55940<smiles>CCCCCCC(C)(C)c1ccc([C@@H]2C[C@H](O)C[C@H]3CC[C@H](CO)C[C@H]32)c(O)c1</smiles>

Agonist/ $\mathrm{CB}_{1}$

Anti-nociceptive

Little, Compton, Johnson, Melvin, and Martin (1988) 
Table 1 (continued)

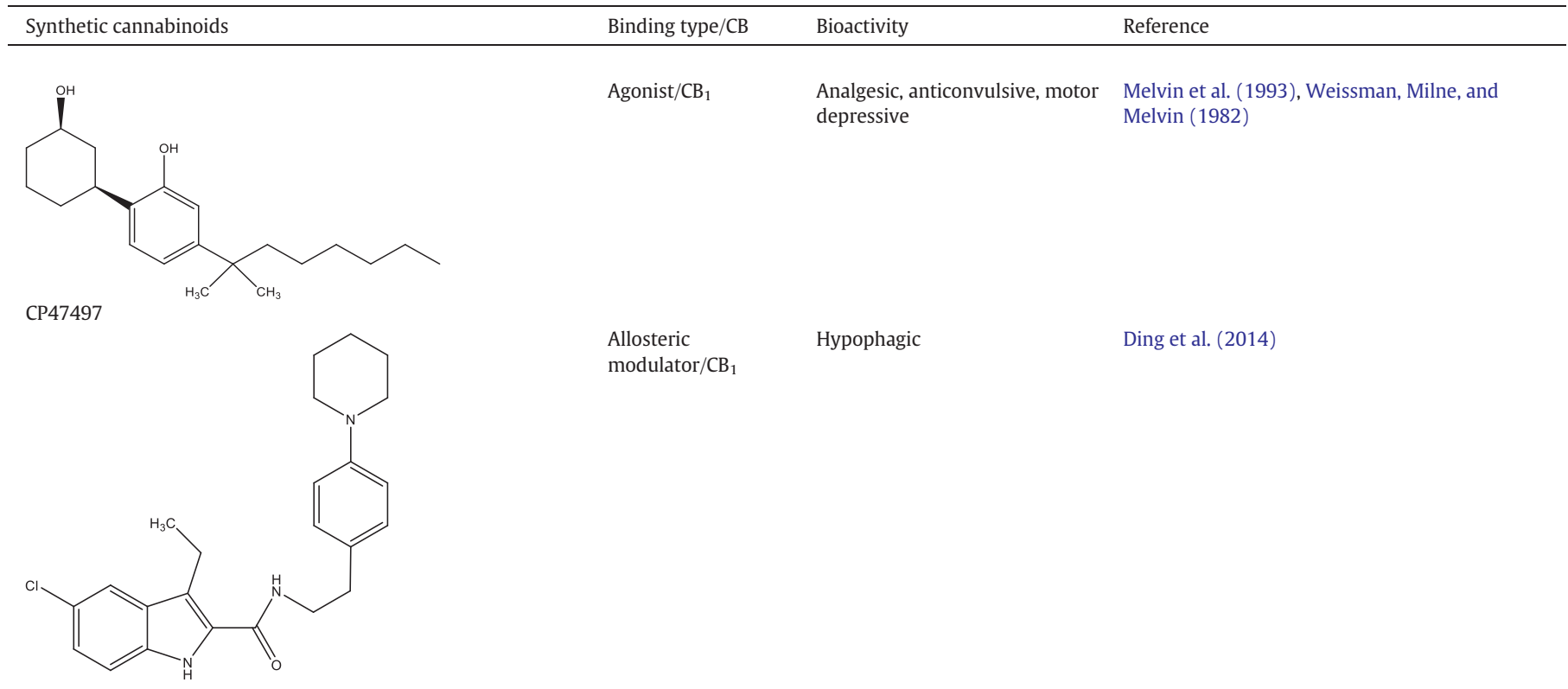

Org27569

Aminoalkylindoles

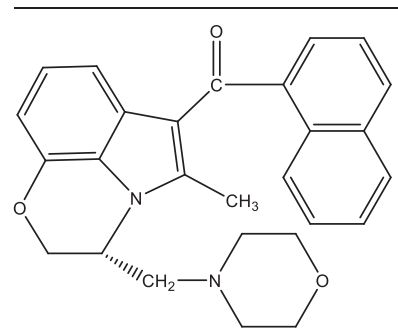

R-(+)-WIN55212<smiles>CCCn1c(C)c(C(=O)c2cccc3ccccc23)c2ccccc21</smiles>

JWH-015<smiles>COc1ccc2c(c1)c(CCN1CCOCC1)c(C)n2C(=O)c1cccc(Cl)c1Cl</smiles> 
Table 1 (continued)

\begin{tabular}{|c|c|c|c|}
\hline Synthetic cannabinoids & Binding type/CB & Bioactivity & Reference \\
\hline \multicolumn{4}{|l|}{ Eicosanoids } \\
\hline & Agonist/ $\mathrm{CB}_{1}$ & $\begin{array}{l}\text { Analgesic, antiemetic, orexigenic, } \\
\text { anti-proliferation, anti-migration }\end{array}$ & $\begin{array}{l}\text { Chakravarti et al. (2014), Guindon and Hohmann } \\
\text { (2011) }\end{array}$ \\
\hline \multicolumn{4}{|l|}{ Methanandamide } \\
\hline & Agonist/CB 1 & $\begin{array}{l}\text { Anti-depressant, } \\
\text { anti-nociceptive }\end{array}$ & $\begin{array}{l}\text { Guindon and Hohmann (2011), Rutkowska and } \\
\text { Fereniec-Goltbiewska (2006) }\end{array}$ \\
\hline
\end{tabular}

Arachidonyl-2-chloroethylamide (ACEA)<smiles>C=C(CCC/C=C\C/C=C\C/C=C\C/C=C\CCCCC)NC1CC1</smiles>

Arachidonylcyclopropylamide (ACPA)

Others<smiles>Cc1c(C(=O)NN2CCCCC2)nn(-c2ccc(Cl)cc2Cl)c1-c1ccc(Cl)cc1</smiles>

Antagonist $/ \mathrm{CB}_{1}$ neuropsychiatric effects
Boekholdt and Peters (2010), Boyd and Fremming (2005), Carai, Colombo, and Gessa (2005)

SR141716A (Rimonabant)<smiles>Cc1ccc(Cn2nc(C(=O)N[C@H]3C(C)(C)C4(C)CC[C@]3(C)C4)cc2-c2ccc(Cl)c(C)c2)cc1</smiles> 
recently, $\mathrm{CB}_{1}$ 's modulation has been implicated in olfaction, a process involved in food intake, visual perception and social interaction and a proposed putative marker for schizophrenia and autism ( $\mathrm{Hu}, 2016)$. Rimonabant was also shown to participate in pharmacological and behavioral effects independent of $\mathrm{CB}_{1}$ receptor activation as it is an agonist/antagonist of the transient receptor potential vanilloid receptor 1 (TRPV1) (Hu, 2016). Therefore, Rimonabant exerted olfactory discrimination deficit by modulating both $\mathrm{CB}_{1}$ and TRPV1 receptors.

Direct interactions with the $\mathrm{CBs}$ are not the only pathways to participate in disease amelioration. Research on the $\mathrm{CB}_{2}$ antagonist, Rimonabant analogue, SR144528 is believed to exhibit anti-obesity and anti-diabetic properties achieved in part through its inhibition of $\mathrm{CB}_{1} \mathrm{CB}_{2}$ induction of orexin $\mathrm{A}$ /orexin 1 receptor (OXR1). OXR1 is a GPCR protein that regulates feeding disorder and like $\mathrm{CB}_{1}$ is expressed in the lateral hypothalamus. In a heterologous model that co-expressed both GPCRs, $\mathrm{CB}_{1}$ was shown to induce orexin-mediated mitogenactivated protein kinase activation more than 100 fold, an effect that was attenuated by the $\mathrm{CB}_{1}$ antagonist/inverse agonist, SR141716/ Rimonabant (Hilairet, Bouaboula, Carriere, Le Fur, \& Casellas, 2003). Furthermore, cannabinoid-opioid cross-modulation has been implicated in antinociception, hypothermia, sedation and reward (Wang, Zhang, et al., 2016). Recent studies have shown that a $\mathrm{CB}_{1}$ antagonist delayed long-term hyperexcitability after brain injury by i) inhibiting longterm up-regulation of $\mathrm{CB}_{1}$ receptors in the hippocampus, ii) exhibiting long-term potentiation of dynorphin, iii) no impact on the up-regulation of $\mathrm{KOR}$ (another rhodopsin GPCR) in hippocampus and iv) reverse the overexpression of mGluR5 in the late stage of brain injury (Wang, Zhang, et al., 2016). SR141716 also participated in the enhancement of ischemia-induced glutamate release after prolonged alcohol withdrawal (Zheng, Wu, Dong, Ding, \& Song, 2015).

The research on the synthetic $\mathrm{CB}$ antagonists although promising are associated with unideal convoys and so many have been pulled from commercial markets and clinical trials. Rimonabant was approved by the European Union in 2006 to treat diabetes but was discontinued from commercial markets and clinical trials two years later because of serious risk of psychiatric disorders (Sanofi-aventis, 2008). Taranabant (MK-0364) and otenabant (CP-945,598) were both discontinued in phase III clinical trials for treating obesity due to the risk/reward ratio (Aronne et al., 2010; Pfizer, 2008; Pharmacodia, 2008) and Surinabant (SR147778) was discontinued from clinical trials for smoking cessation (R \& D Focus Drug News, 2008). Some therefore believe that the current thrust towards tackling these adverse effects is to restrict binding associations to peripheral $\mathrm{CB}_{1}$ and so limit the crossing of the blood brain barrier (BBB) by small molecules (Chorvat, 2013). 
Table 2

Natural CB ligands, their structures, binding affinities and bioactivities.

\begin{tabular}{|c|c|c|c|}
\hline Phytocannabinoids & ECS modulation & Bioactivity & Reference \\
\hline \multicolumn{4}{|l|}{ Classical } \\
\hline $\mathrm{CH}_{3}$ & $\begin{array}{l}\text { Agonist/CB } 1 \\
\mathrm{CB}_{2}\end{array}$ & $\begin{array}{l}\text { Analgesic, anorexia, antiemetic, } \\
\text { orexigenic }\end{array}$ & $\begin{array}{l}\text { Abrams (2016), Beal et al. } \\
\text { (1995), Gonzalez-Rosales } \\
\text { and Walsh (1997) }\end{array}$ \\
\hline
\end{tabular}

$\Delta 9-\mathrm{THC}$, dronabinol/ $\Delta 9-\mathrm{THC}$

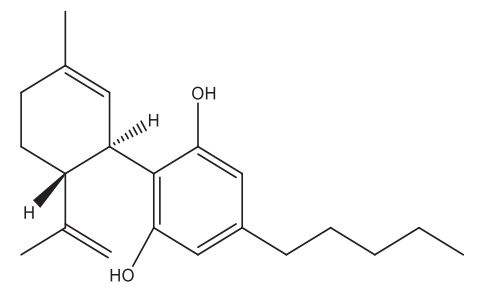

Cannabidiol<smiles>CCCCCc1cc(O)c2c(c1)OC(C)(C(C)(C)C)c1ccc(C)cc1-2</smiles><smiles>CCCCCc1cc(O)c2c(c1)OC(C)(CCC=C(C)C)C=C2</smiles>

Cannabichromene<smiles>CCCCCc1cc(O)c(CC=C(C)CCC=C(C)C)c(O)c1</smiles>

Cannabigerol<smiles>CCCc1cc(O)c2c(c1)OC(C)(C)[C@@H]1CCC(C)=C[C@H]21</smiles>

Antagonist, Anti-inflammatory, antioxidant Ligresti et al. (2006) weak affinity for anti-proliferative, apoptosis inducer, Pertwee (2008)

$\mathrm{CB}_{1} / \mathrm{CB}_{2} \quad$ neuroprotective
Agonist $/ \mathrm{CB}_{1}, \mathrm{CB}_{2}$ Analgesic

Sofia, Vassar, and Knobloch (1975)
Agonist, antagonist $/ \mathrm{CB}_{1}$, $\mathrm{CB}_{2}$, TRPA1,
Analgesic, anti-inflammatory.

Antimicrobial, anti-proliferative in tumour models $<$ increase neural stem cell viability
Appendino et al. (2008), Izzo et al. (2012), Ligresti et al. (2006), Maione et al. (2011)
Agonist/ $\mathrm{CB}_{1}$, Anti-inflammatory, anti-cancer

$\mathrm{CB}_{2}$, TRPA1, neuroprotective, orexigenic
Borrelli et al. (2013), Granja et al. (2012), Valdeolivas et al. (2015)

\section{Antagonist, Anti-inflammatory partial}

agonist $/ \mathrm{CB}_{1}, \mathrm{CB}_{2}$

Bolognini et al. (2010)
$\mathrm{CB}_{1}$ independent
Anticonvulsant

Amada, Yamasaki, Williams, and Whalley (2013), Hill et 


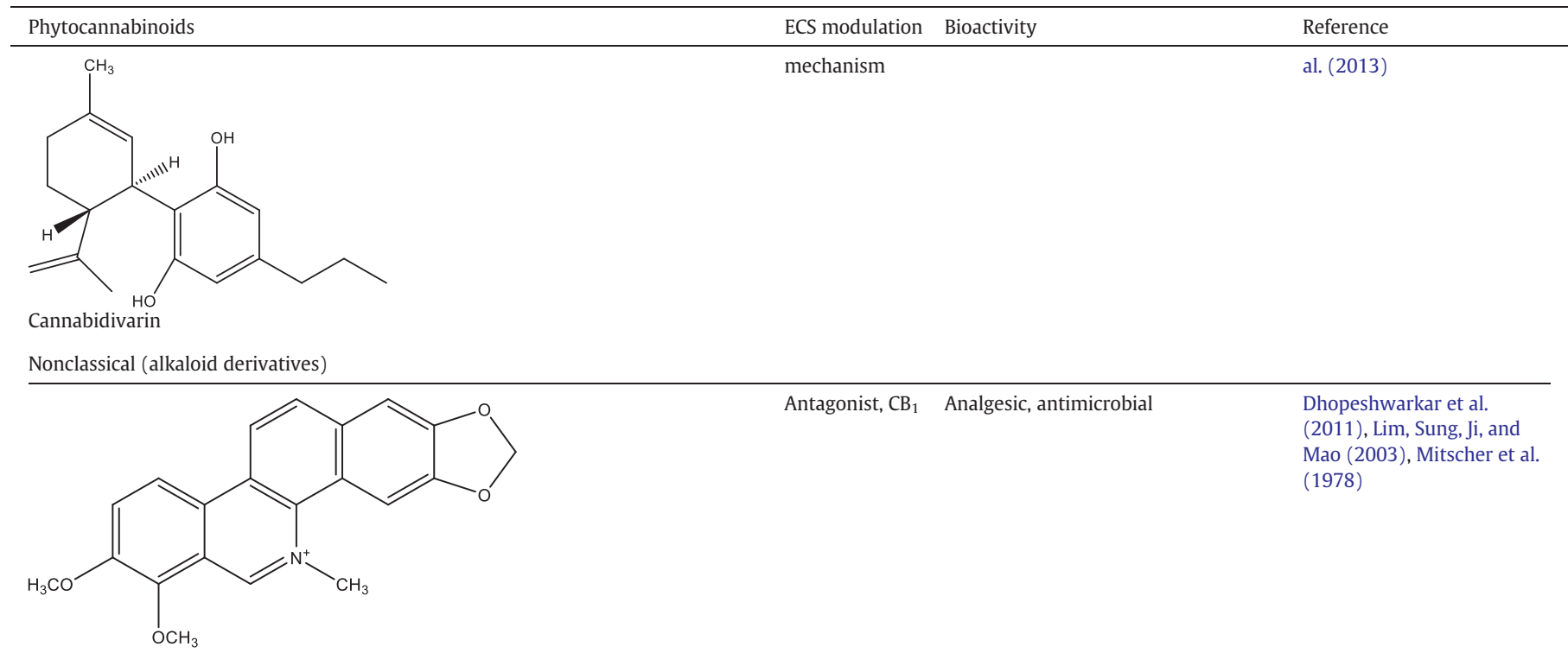

Chelerythrine<smiles>C[n+]1cc2c3c(ccc2c2ccc4cc5c(cc4c21)OCO5)OCO3</smiles>

Antagonist, $\mathrm{CB}_{1} \quad$ Anticancer, apoptosis inducer, improved gut peristalsis
Das and Khanna (1997),

Dhopeshwarkar et al.

(2011), Sun et al. (2010)

Sanguinarine

Nonclassical (alkylamide derivatives)<smiles>C/C=C\C=C/CC/C=C/C=C/C(=O)NCC(C)C</smiles>

\section{$\mathrm{CB}_{2}$ agonist,} inhibit FAAH
Immunomodulatory

(a)
Guiotto et al. (2008), Raduner et al. (2006)

Dodeca-2E,4E,8Z,10Z-tetraenoic acid isobutylamide<smiles>CCCCCCC/C=C/C=C/C(=O)NCC(C)C</smiles>

\section{Dodeca-2E,4E-dienoic acid isobutylamide}

Nonclassical (cannabinomimetic derivative)

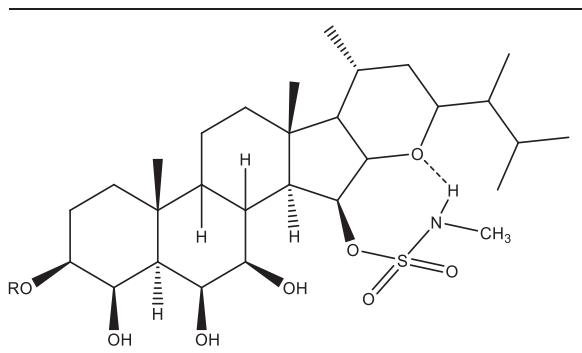

Haplosamates $\mathrm{A}\left(\mathrm{R}=\mathrm{O}, \mathrm{SO}_{3} \mathrm{Na}\right)$ 


\begin{tabular}{|c|c|c|c|}
\hline Phytocannabinoids & ECS modulation & Bioactivity & Reference \\
\hline \multicolumn{4}{|c|}{ Nonclassical (terpenoid derivatives) } \\
\hline & $\begin{array}{l}\text { Agonist/ } \mathrm{CB}_{1} \text {, } \\
\mathrm{CB}_{2}\end{array}$ & Anti-inflammatory, anti-nociceptive & da Silva et al. (2011) \\
\hline
\end{tabular}<smiles>C=C1CCC=C2CC[C@H](C(C)(C)C)C[C@]12CC(C)(C)C</smiles>

Agonist/ $\mathrm{CB}_{2} \quad$ Anti-inflammatory Jürg Gertsch et al. (2008)

ß-Caryophyllene



$\mathrm{CB}_{1}, \mathrm{CB}_{2}$ dependent mechanisms
Analgesic, anti-inflammatory, anti-nociceptive
Dutra et al. (2012)<smiles>CC(=O)O[C@]1(C)CC[C@@]2(C)CC[C@]3(C)C4=CC=C5C(=CC(=O)C(O)=C5C)[C@]4(C)CC[C@]3(C)[C@]21C</smiles>

Inhibitor/MAGL Anti-inflammatory, antioxidant, chemoprotective
King et al. (2009)

Pristimerin

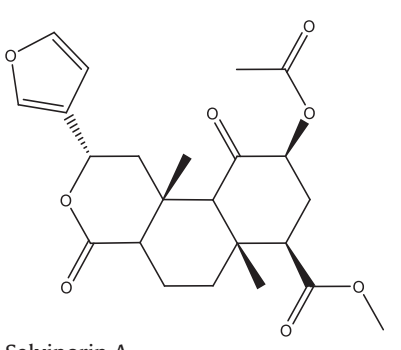

Weak affinity $/ \mathrm{CB}_{1} / \mathrm{CB}_{2}$ neuromodulatory
Braida, Limonta, Pegorini, et al. (2007), Capasso, Borrelli, Cascio, et al. (2008) 


\begin{tabular}{|c|c|c|c|}
\hline Phytocannabinoids & ECS modulation & Bioactivity & Reference \\
\hline \multicolumn{4}{|c|}{ Nonclassical (polyphenol derivatives) } \\
\hline & $\begin{array}{l}\text { Antagonist, } \\
\text { inverse } \\
\text { agonist } / \mathrm{CB}_{1}, \mathrm{CB}_{2}\end{array}$ & $\begin{array}{l}\text { Anti-inflammatory, antioxidant, } \\
\text { immunomodulatory, neuroprotective }\end{array}$ & $\begin{array}{l}\text { Hassanzadeh and } \\
\text { Hassanzadeh (2012), Seely, } \\
\text { Levi, and Prather (2009) }\end{array}$ \\
\hline
\end{tabular}

Curcumin<smiles>Oc1cc(O)c2cc(O)c(-c3ccc(O)c(O)c3)[o+]c2c1</smiles><smiles>Oc1cc(O)c2cc(O)c(-c3cc(O)c(O)c(O)c3)[o+]c2c1</smiles>

Delphinidin

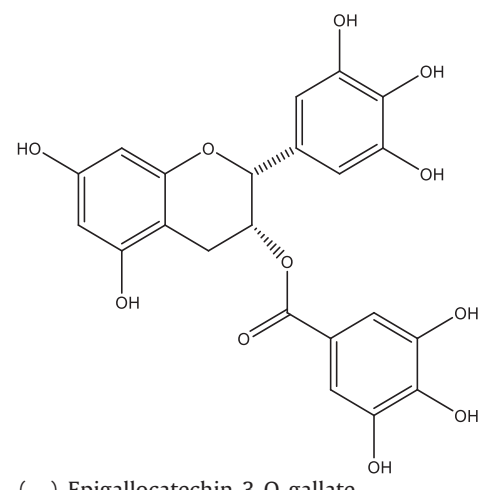

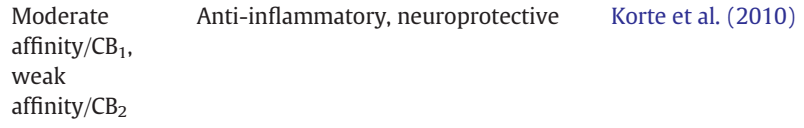
Moderate Anti-inflammatory, neuroprotective $\quad$ Korte et al. (2010)
affinity $/ \mathrm{CB}_{1}$, weak affinity $/ \mathrm{CB}_{2}$

(-)-Epigallocatechin-3-0-gallate<smiles>Oc1cc(O)c2c(c1)O[C@H](c1ccc(O)c(O)c1)[C@H](O)C2</smiles>

(-)-Epicatechin
Negligible affinity for $\mathrm{CB}_{1} / \mathrm{CB}_{2}$
Anti-inflammatory, neuroprotective

Korte et al. (2010)

Others<smiles>CC(C)CNC(=O)/C=C/C=C/CCCCCC/C=C/c1ccc2c(c1)OCO2</smiles>

Indirect agonist/ $\mathrm{CB}_{1}$
Cannabimimetic effects including analgesic and thermoregulation
Nicolussi et al. (2014) 
3.3. Natural products as ligands of the ECS, better efficacy than synCBs or not?

It has been highlighted that a natural product, $\triangle 9$-THC paved the way for understanding the role of CBs and their eCBs. Of the over 100 phyCBs present in Cannabis sativa, the major constituents within the plant are $\triangle 9$-THC, cannabidiol (CBD) and cannabinol (CBN) (Russo, 2011). Unlike $\Delta 9$-THC (Cumella et al., 2012), CBD and CBN are non-psychotropic phytocannabinoids (Pertwee, 2006a) and exhibit poorer binding affinities to the CBs. However, findings thus far have uncovered enhanced efficacy (considering the reduced psychotropic effects) when using the combination therapy, $\mathrm{CBD}$ and $\triangle 9$-THC which will be the primary focus of this section. $\triangle 9$-THC binds with similar affinities to $\mathrm{CB}_{1}$ and $\mathrm{CB}_{2}$ receptors at nanomolar concentrations. It behaves like a $\mathrm{CB}_{1}$ receptor partial agonist and $\mathrm{CB}_{1} / \mathrm{CB}_{2}$ receptor antagonist (Pertwee, 2008). Under the trademark Marinol, $\triangle 9$-THC is used to treat anorexic associated disorders in patients with AIDS and nausea related conditions in patients on certain chemotherapies (Hazekamp \& Grotenhermen, 2010). The lack of euphoric accompaniment by Marinol could be due to its dose, while the other trademark, Nabilone is used to treat chemotherapy induced nausea and vomiting. $\triangle 8$-THC has similar affinities for $\mathrm{CB}_{1}$ and $\mathrm{CB}_{2}$ receptors akin to $\triangle 9$-THC (Paronis, Nikas, Shukla, \& Makriyannis, 2012). Other classically derived phyCBs are Cannabigerol (CBG), Cannabichromene (CBC), Tetrahydrocannabivarin (THCV), Cannabidivarin (CBDV) and these and more along with modulatory effects on the ECS are outlined in Table 2.

PhyCBs have been shown to exhibit promising efficacy towards many conditions including, i) CNS disorders (Hill, Williams, Whalley, \& Stephens, 2012); ii) convulsions (Hill et al., 2010); iii) neurodegeneration (Gilbert, Kim, Waataja, \& Thayer, 2007; Zani, Braida, Capurro, \& Sala, 2007), iv) epilepsy (Cunha et al., 1980; dos Santos, Hallak, Leite, Zuardi, \& Crippa, 2015); v) sleep disorders (Murillo-Rodríguez (Murillo-Rodriguez, Millan-Aldaco, Palomero-Rivero, Mechoulam, \& Drucker-Colin, 2006) and vi) inflammation (Costa et al., 2004).

The structural similarities shared between $\triangle 9$-THC and the eCBs, $A E A$ and 2-AG explain the ability of this phyCB to activate $C_{1}$ and $\mathrm{CB}_{2}$. $\triangle$ 9-THC binds to both receptors $\left(\mathrm{CB}_{1}\right.$ and $\left.\mathrm{CB}_{2}\right)$ with higher affinity (nM range) than its corresponding ( + -)cis (6aS, 10aS) enantiomer $(+)$ $\triangle 9-\mathrm{THC})$ and with equal or greater affinity than other phyCBs, $(-)-\Delta 8$ THC, $\triangle 9$-THCV, CBD, CBG and CBN. However, $\triangle 9$-THC exhibits lower affinity and efficacy than synCBs, HU-210, CP55940 and R-(+)WIN55212 (Pertwee, 2008) and the eCBs (Pertwee, 2008). Additional to its partial agonism of the CBs, $\triangle 9$-THC activated $\mathrm{G}$ proteins by $44 \%$ (specifically for the interaction of $\mathrm{CB}_{2}$ receptors with $\mathrm{G}_{\mathrm{i}}$ ) and $\mathrm{CB}_{1}$-catalyzed $G_{i}$ by $56 \%$ (Glass \& Northup, 1999). These observed effects were weaker than the synCB, HU-210 and the eCB, AEA. Akin to the eCBs, $\triangle 9$-THC can inhibit ongoing neurotransmitter release through neuronal presynaptic $\mathrm{CB}_{1}$ receptors (Pertwee \& Ross, 2002). This is believed to account for many of the $\triangle 9$-THC mediated $C_{1}$ effects such as analgesia, muscle relaxation, anti-emesis or appetite stimulation as well as psychotropic properties (Pertwee, 2000). Furthermore, $\Delta 9$ THC antinociceptive effects were shown to be mediated through $\beta$-arrestin- 2 as $\beta$-arrestin-2-KO mice failed to desensitize their $\mathrm{CB}_{1}$ receptors after $\triangle 9$-THC stimulus and therefore were more sensitive to $\triangle 9$-THC (Breivogel, Lambert, Gerfin, Huffman, \& Razdan, 2008; Nguyen et al., 2012). $\triangle 9$-THC is not as selective for $\mathrm{CB}_{1}$ (Kreitzer, 2005; Vaughan \& Christie, 2005), as its ( $\left.\mathrm{CB}_{1}\right)$ mediated activation has been linked to the activation of other neurotransmitters like dopamine and acetylcholine (Gardner, 2005; Nagai et al., 2006; Pertwee \& Ross, 2002; Pisanu, Acquas, Fenu, \& Di Chiara, 2006; Pistis et al., 2002), which is believed to restrict its clinical applicability to treating anorexia, nausea and vomiting. Although $\mathrm{CB}_{1}$ commonly facilitates inhibition of continuous neuronal transmitter release (on which it is located), it's $\left(\mathrm{CB}_{1}\right)$ activation as shown prior, sometimes results in an opposite effect. These mixed effects that $\triangle 9$-THC participates in in vivo is a possible reason why this phyCB exhibits both excitant and depressant effects as it has been shown to demonstrate anticonvulsant properties in certain in vivo models but proconvulsant activities in others (Berrendero \& Maldonado, 2002; Braida, Limonta, Malabarba, Zani, \& Sala, 2007; Chiu, Olsen, Borys, Karler, \& Turkanis, 1979; Colasanti, Lindamood, \& Craig, 1982; Dewey, 1986; Fish, Consroe, \& Fox, 1983; Patel \& Hillard, 2006; Schramm-Sapyta et al., 2007; Turkanis \& Karler, 1981; Wallace, Blair, Falenski, Martin, \& DeLorenzo, 2003). Therefore, perhaps combination therapies of inhibitors of these other neurotransmitters (acetylcholine and dopamine), further discussed (Babitha, Sahila, Bandaru, Nayarisseri, \& Sureshkumar, 2015; Čolović, Krstić, Lazarević-Pašti, Bondžić, \& Vasić, 2013; Wang, Shen, et al., 2016) with $\Delta 9-T H C$ can be explored. One such example is rivastigmine (Gawel et al., 2016). It should be noted however, that a comprehensive overview of the function, production and associated targets of these neurotransmitters is critical when deciding ideal combinations. For example, the loss of dopaminergic neurons in the substantia nigra par compacta has been implicated in the onset of certain neurodegenerative diseases like PD, and so some studies demonstrate that the stimulation of dopamine
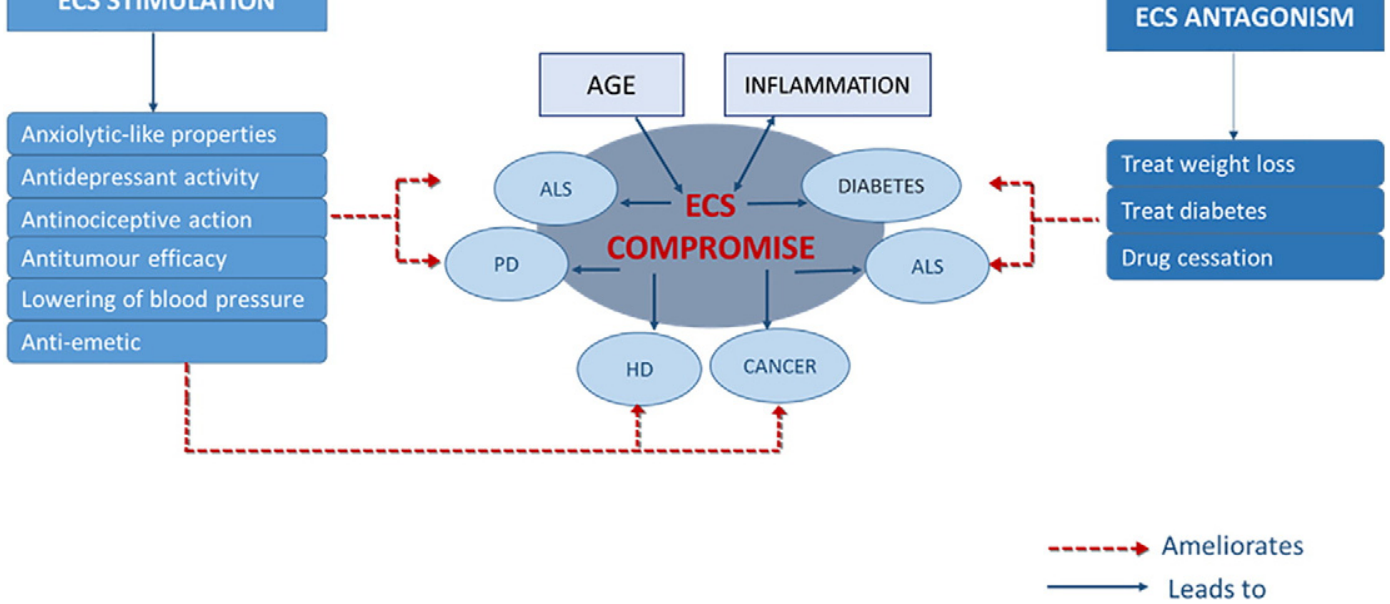

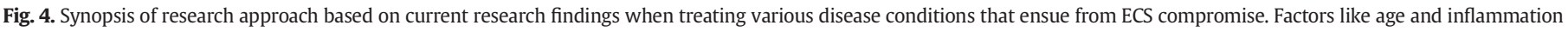

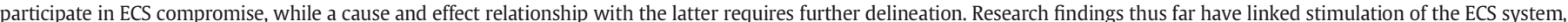

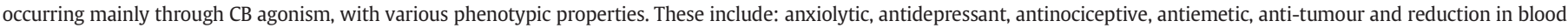

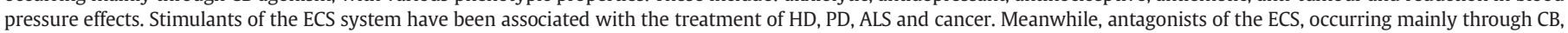
have been associated with treating weight loss (which has implications for treating cardiovascular morbidities), diabetes and drug cessation. 
confers neuroprotective properties (Ablat et al., 2016). On the other hand, overstimulation of dopamine participates in drug dependence (Dackis \& Gold, 1985). Hence, further delineation is needed to identify appropriate combinations with $\triangle 9-\mathrm{THC}$ that could generate optimum efficacy with minimal side-effects. In addition to the mixed stimulatory-inhibitory effects of $\triangle 9$-THC on $\mathrm{CB}_{1}$ mediated neurotransmission release/inhibition, the phyCB can inhibit central neurotransmission. As $\triangle 9$-THC exhibits lower affinity and efficacy compared to some phyCBs and eCBs, its particular demonstrable bioactivity is believed to be governed by the CBs' density and their coupling efficiencies (Childers, 2006; Pertwee, 2006b). Hence, in certain cells/tissues, $\Delta 9-\mathrm{THC}$ may not exhibit agonistic traits but block the efficacy of other ligands that demonstrate higher binding affinities (Patel \& Hillard, 2006; Sim et al., 1996). The partial agonistic traits of $\Delta 9$-THC can therefore be clinically applicable to disease conditions that result in an upregulation of the CBs in a cell/tissue specific manner. Such upregulation is thought to increase the selectivity and efficacy of partial CB agonists like $\triangle 9$-THC.

The other well researched phyCB is CBD, a key cannabinoid constituent in Cannabis sativa that represents up to $40 \%$ of cannabis extracts (Grlic, 1976). However, unlike $\Delta 9-\mathrm{THC}$, it is well tolerated and does not present with psychoactive properties; CBD's bioactivities are thought to be a priori its innate chemical structure, specifically its hydroxyl groups (Mechoulam, Parker, \& Gallily, 2002) rather than its ligand-mediated signal transduction effect. CBD's bioactivities are more defined around its neuroprotective effects although there is preclinical evidence of its anti-tumorigenic property (McAllister, Christian, Horowitz, Garcia, \& Desprez, 2007). This is believed to occur because of one or more of the following; its ability to impede adenosine uptake (Liou et al., 2008), down-regulate the enzymes FAAH and 5-lipoxygenase (Capasso, Borrelli, Aviello, et al., 2008; Massi et al., 2008), or bind both transient receptor potential vanilloid 1 (TRPV1) (Iannotti et al., 2014) and 5-hydroxytryptamine (serotonin) receptor 1A (5-HT1A) receptors (Russo, Burnett, Hall, \& Parker, 2005). The neuroprotective properties of CBD are thought to be independent of the ECS (De Filippis et al., 2010) except in select conditions (Bisogno et al., 2001; Castillo, Tolon, Fernandez-Ruiz, Romero, \& Martinez-Orgado, 2010; De Filippis et al., 2008). Nonetheless, emerging research shows that despite the low affinity $C B D$ displays for the $C B s$, this phyCB exhibits possible noncompetitive binding to $C_{1}$ and $\mathrm{CB}_{2}$, possibly as an inverse agonist at certain concentrations below which it binds to both $\left(\mathrm{CB}_{1}\right.$ and $\left.\mathrm{CB}_{2}\right)$ orthosteric sites (Lunn et al., 2006; MacLennan, Reynen, Kwan, Bonhaus, \& Martin, 1998; Thomas et al., 2007). Further, $C B D$ also demonstrates antagonistic effects on $\mathrm{CB}_{1}$ agonists, CP55940 (Petitet, Jeantaud, Reibaud, Imperato, \& Dubroeucq, 1998) and $R-(+)$-WIN55212 (Pertwee \& Ross, 2002) in various in vitro and preclinical models.

CBD's neuroprotective effects are thought to be because of i) its ability to restore the normal balance between oxidative events and antioxidant endogenous mechanisms (Fernandez-Ruiz, Garcia, Sagredo, Gomez-Ruiz, \& de Lago, 2010), often dysregulated in neurodegenerative disorders; ii) the upregulation of endogenous antioxidant enzymes to control oxidative stress, specifically transcription factor nuclear factorerythroid 2-related Factor 2 (Nrf-2) induced signaling; iii) its antiinflammatory activity via the canonical pathway (Walter et al., 2003), limiting ATP induced-increases in intracellular $\mathrm{Ca}^{+}$levels and NO production in microglial cells (Martin-Moreno et al., 2011) and other mechanisms discussed further (Fernandez-Ruiz et al., 2013). While CBD has also shown evidence of neuroprotection via an ECS independent pathway (Abood, Rizvi, Sallapudi, \& McAllister, 2001; Gilbert et al., 2007), the modulation of $\mathrm{CB}_{1}$ also plays a role in this paradigm as observed in in vitro (Abood et al., 2001; Gilbert et al., 2007) and preclinical (Chen \& Buck, 2000; El-Remessy et al., 2003; van der Stelt et al., 2001; Zani et al., 2007) models. Furthermore, other phyCBs, $\triangle 9$-THC and THCV's agonistic properties of the $\mathrm{CB}_{2}$ have also been implicated in preclinical neuroprotection (Garcia et al., 2011; Tourino, Zimmer, \& Valverde, 2010).

The promising neuroprotective potential of CBD has propelled its elevation of research from basic science to clinical, especially since it seems to attract less psychoactive side-effects than its $\Delta 9$-THC counterpart. There is compelling preclinical evidence supporting the efficacy of CBD's neuroprotection against neonatal ischemic insults (Alvarez et al., 2008; Castillo et al., 2010; Fernandez-Ruiz et al., 2010; Lafuente et al., 2011). Additionally, CBD was shown to minimize necrotic and apoptotic damage brought about by glucose-oxygen deprivation in newborn mice using the newborn hypoxic-ischemic brain damage (NHIBD) model (Castillo et al., 2010). The mechanism of action is believed to occur through CBD's normalization of glutamate and cytokines in addition to the inhibition of iNOS and COX-2. Co-incubation with a $\mathrm{CB}_{2}$ antagonist abolished the observed effects which strongly suggests the role of $\mathrm{CBs}$ in CBD's observed neuroprotection cascade in newborns (Castillo et al., 2010).

CBD's application in combination with other phyCBs has revealed ideal synergism. CBD combined with $\triangle 9$-THC, akin to the drug Sativex was shown to be effective in treating Huntington's disease in preclinical models (rats lesioned with 3-nitropropionic acid) (Sagredo, Ramos, Decio, Mechoulam, \& Fernandez-Ruiz, 2007; Sagredo et al., 2011) and believed to occur via $\mathrm{CB}_{1}$ and $\mathrm{CB}_{2}$ dependent pathways. Another model that utilized malonate induced lesions in rats seemed to engage a $\mathrm{CB}_{2}$ pathway only as $\mathrm{CBD}$ alone was ineffective while other $\mathrm{CB}_{2}$ agonists were effective (Sagredo et al., 2009). The combination therapy of $\mathrm{CBD}$ and $\triangle 9$-THC towards treating HD has thus far exhibited promising efficacy which has already transitioned them to clinical trials (Fernandez-Ruiz et al., 2013). PD is another neurodegenerative disorder that seems to be mitigated by the action of $\mathrm{CBD}$ by $\mathrm{CB}_{1}$ independent mechanisms (Garcia et al., 2011; Garcia-Arencibia et al., 2007; Lastres-Becker, Molina-Holgado, Ramos, Mechoulam, \& Fernandez-Ruiz, 2005) as $C_{1}$ is associated with reduced motor activity as evidenced from clinical studies (Fernandez-Ruiz, 2009). Therefore, it is believed that the activation of $\mathrm{CB}_{2}$ and not $\mathrm{CB}_{1}$ might be more ideal for treating ECS associated diseases. However, such an angle could potentially preclude opportunities to treat $\mathrm{CB}_{1}$ associated morbidities. Hence, like Sativex, perhaps other combinations with CBD could be explored e.g. $\mathrm{CBD}$ with $\mathrm{CB}_{1}$ inhibitors like the phyCB, THCV that showed preclinical evidence of treating PD (Garcia et al., 2011) and $\mathrm{CBD}$ with $\alpha, \beta$-amyrin, a potent $\mathrm{CB}_{1}$ triterpenoid phyCB (da Silva et al., 2011) discussed more below.

Currently, Sativex, a 1:1 combination of $\triangle 9-$ THC and CBD is used to treat neuropathic pain, spasticity, overactive bladder and other symptoms of multiple sclerosis (Rahn \& Hohmann, 2009; Russo, 2008). Many phyCBs are undergoing clinical trials for various ailments as outlined in a review (Hazekamp \& Grotenhermen, 2010), this includes tetrahydrocannabinol, $\triangle 9$-THC, CBD, dronabinol, marinol, nabilone,

The challenge that exists when utilizing exogenous $\mathrm{CB}_{1}$ agonists is the onset of psychosomatic symptoms and recently, overactive $\mathrm{CB}_{1}$ was shown to participate in type 2 diabetic nephropathy (Jourdan et al., 2014). So the question lies in how to strike a balance, maintaining the efficacy of the phyCBs while blocking the side-effects. So far we have explored a possible mechanism that accounts for the side-effects of $\triangle 9$-THC which could be the upregulation of certain neurotransmitters, acetylcholine and dopamine upon $\mathrm{CB}_{1}$ activation. Indeed, the partial agonism that $\triangle 9$-THC seems to exert is thought to reduce its efficacy especially when there is normal to suboptimal levels of $\mathrm{CB}_{1}$. On the other hand, this type of binding is believed to hold promise in instances where $\mathrm{CB}_{1}$ and $\mathrm{CB}_{2}$ activation are elevated and particularly localized to certain tissues as binding affinity to the phyCB would be more restricted to those tissues/cells with elevated $\mathrm{CB}$ expression. This phenomenon is not uncommon as the cytochrome P450 (CYP) CYP1B1 enzyme whose presence is usually induced by the activation of the aryl hydrocarbon signal transduction pathway is believed to hold promise in treating certain cancers. CYP1B1's presence is often times elevated in cancerous tissues like prostate relative to normal neighbouring tissue (Yang et al., 2008) and so chemotherapy prodrugs that are metabolized only by CYP1B1 are believed to hold promise as target-specific anticancer drugs (Roos \& Bolt, 2005). Although 
CYP1B1 is an enzyme and $\mathrm{CB}_{1}$ is a receptor, the principle remains as the upregulation of $C B s$ can be a positive angle for utilizing $\triangle 9$-THC, the potential side-effects of this phyCB can be mitigated using combination therapies as discussed prior. A polypharmacology approach is not uncommon when treating diseases especially since the lock and key approach towards disease amelioration seem to produce less than ideal outcomes (Medina-Franco, Giulianotti, Welmaker, \& Houghten, 2013).

Currently, we know that ligand binding of $\mathrm{CB}_{1}$ can participate in numerous outcomes as shown in Figs. 2 and 4 and even much more remains to be elucidated. Many reviews have been published on the effects of natural products on the $\mathrm{CB}_{1}$ at the in vitro and preclinical levels (Di Marzo \& Piscitelli, 2015; Gertsch, Pertwee, \& Di Marzo, 2010; McAllister, Soroceanu, \& Desprez, 2015; Sharma, Sadek, Goyal, Sinha, \& Kamal, 2015) and so will not be reiterated here. These reviews have highlighted the modulatory effects of phyCBs that either exhibit direct or indirect impact on the ECS. Overall, many alkaloids, alkylamide derivatives, terpenes, polyphenols, polyacetylene and various fatty acids and fatty acid amides, from terrestrial and marine plant sources have shown in vitro and/or preclinical evidence of ECS modulation towards efficacy. Table 2 in this review highlights those phyCBs that have exhibited CB selectivity and/or potent direct or indirect ECS modulation, of these, noteworthy ones are discussed below.

We previously examined in detail the effects of 2 classical phyCBs that have and continue to be researched for efficacy. However, other phyCBs also hold promise. Non-classical CBs, fatty acid derivatives, $\mathrm{N}$ alkylamides from the Echinacea spp. that show some structural similarity to the eCB, $\mathrm{AEA}$, demonstrate preferred binding affinity to the $\mathrm{CB}_{2}$ resulting in elevated levels of intracellular $\mathrm{Ca}^{+}$ions (Gertsch, Raduner, \& Altmann, 2006), also observed with $\mathrm{CB}_{1}$ /ligand coupling in human neuroblastoma SH-SY5Y cells (Marini et al., 2009). The select binding of $\mathrm{CB}_{2}$ is believed to be an ideal route and so compounds with restrictive capacity to peripheral tissues and so unable to cross the BBB (Pertwee, 2009) may minimize the psychoactive properties exhibited with $\mathrm{CB}_{1}$ agonists. However, alkylamides (dodeca-2E,4E,8Z,10Ztetraenoicacidisobutylamide) have been shown to cross the BBB; nonetheless their poor binding affinity to $\mathrm{CB}_{1}$ might present a promising option for treating $\mathrm{CB}_{2}$ associated disorders. Furthermore, the observed effects of the alkylamides hold additional implications, such as the treatment of congestive heart failure, as an elevation of intracellular $\mathrm{Ca}^{+}$ions is known to effectuate a positive ionotropic effect. This effect parallels the mode of action exhibited by the cardiac glycosides, digoxin and digitoxin, that inhibit the target molecule, $\mathrm{Na} / \mathrm{K}^{+}$ATPase enzyme. Inhibition of this enzyme causes an imbalance in the ratio of $\mathrm{Na}^{+}$to $\mathrm{K}^{+}$ions that results in elevated intracellular $\mathrm{Ca}^{+}$ions. When this occurs, there is a subsequent increase in the strength of the heart muscles. This has implications for the treatment of congestive heart failure. The elevation in $\mathrm{Ca}^{+}$levels parallel the mode of action exhibited by the cardiac glycosides, digoxin and digitoxin, that inhibit the target molecule, $\mathrm{Na} / \mathrm{K}^{+}$ATPase enzyme. Inhibition of this enzyme causes an imbalance in the ratio of $\mathrm{Na}^{+}$to $\mathrm{K}^{+}$ions that results in elevated intracellular $\mathrm{Ca}^{+}$ions. When this occurs, there is a subsequent increase in the strength of the heart muscles. Alkylamide-based modulation of the ECS also demonstrated implications for anti-inflammatory effects (Raduner et al., 2006) in addition to indirect influence on the ECS through interfering with the bioavailability of eCB precursors (Banni \& Di Marzo, 2010; Di Marzo \& Despres, 2009).

Another family of compounds with promising ECS mediated efficacy is terpenes. $\alpha, \beta$-Amyrin, a pentacyclic triterpene exhibited CB mediated anti-inflammatory and antinociceptive effects and the latter were comparable to synthetic molecules, ACEA and JWH-133 (da Silva et al., 2011 ). While $\alpha, \beta$-Amyrin modulated the activities of both $\mathrm{CB}_{1}$ and $\mathrm{CB}_{2}, \alpha, \beta$-Amyrin was 15,000 fold more selective for $\mathrm{CB}_{1}$ (da Silva et al., 2011), 200-300 fold more potent than $\Delta 9$-THC (Chicca, Marazzi, \& Gertsch, 2012) and did not present with behavioral effects making this phyCB an ideal small molecule warranting further investigations especially in combination therapies. The terpene, $\beta$-caryophyllene of Cannabis sativa is a selective agonist of $\mathrm{CB}_{2}$ receptors (Gertsch, 2008) that exerts anti-inflammatory and analgesic effects in addition to easing neuropathic pain (Zimmer, Treschan, Meier, \& Nosch, 2009). A recent review highlights $\beta$-caryophyllene's multifaceted therapeutic effects including its observed synergy with other GPCR signaling pathways ( $\mu$-opioid receptor dependent pathways) strongly indicating the value of this phyCB to treat ECS associated morbidities (Sharma et al., 2016). The diterpene salvinorin has also confirmed effects from a polypharmacological angle as it is a selective KOR GPCR agonist and CB ligand (Fichna et al., 2009).

More recently, in vitro research shows the antiproliferative effects of the flavonoid, quercitin, mediated by $\mathrm{CB}_{1}$ (Refolo et al., 2015). A review by Guzman (2003) highlights the potential anticancer effects of select cannabinoids, isolates from Cannabis sativa and a fairly recent review (Chakravarti, Ravi, \& Ganju, 2014) provides a more detailed representation of the efficacy of these isolates to treat cancer. On another note, indirect modulation of the ECS was observed in the presence of naturally occurring quinoid terpenoids, pristimerin and euphol through reversibly inhibiting the activity of the enzyme, monoacylglycerol lipase (MAGL). For other phyCBs that exhibit efficacy through the CBs and the ECS, see Table 2.

\section{Concluding remarks and future perspectives}

CBs play an important role effecting many biological switches and so they are targets for treating autoimmune diseases (Cabral \& GriffinThomas, 2009), inflammatory and/or neuropathic pain (Guindon \& Hohmann, 2008), osteoporosis (Karsak et al., 2005), cancer (Velasco, Sanchez, \& Guzman, 2016) and most recently, diabetes (Lu, Dopart, \& Kendall, 2016; Vemuri, Janero, \& Makriyannis, 2008). The latter is an interesting tangent to the well-researched insulin-mediated signal transduction pathway that has been explored for many decades but continues to present challenges of drug resistance and toxicity effects (Kooti, Farokhipour, Asadzadeh, Ashtary-Larky, \& AsadiSamani, 2016). The treatment of diabetes through either the ECS or the insulin-mediated signal transduction pathway holds promise to treating diabetes associated comorbidities, cardiovascular and metabolic disorders, collectively known as the metabolic syndrome.

The transduction of signals through the CBs by means of endogenous ligands has established a foundation for possible exogenous modulators that can mitigate disease initiation and progression. So far, agonists of the CBs are theoretically important for ameliorating neurodegenerative disorders, treating pain and many cancers and evidence of these exists at various stages of research as discussed earlier. On the other hand, antagonists have been shown to primarily play a role in weight loss, diabetes and treating feeding disorders. Yet, the theory of these expectations are not necessarily realised in clinical research and if they are, they are usually accompanied by unbearable side-effects and thus the many drug withdrawals. This is possibly due to the gross oversimplification of the ECS which encompasses a myriad of factors that surround bioactivity outcome. These factors include tissue locale, CB's shapeshifting myriads, CBs' density and their coupling efficiencies, CBs' dimerization with other GPCRs and protein receptors, and other CBs' direct and indirect targets.

Both synthetic and natural ligands of the CBs have demonstrated promising efficacy and indeed the lack of clinical applicability is congruent to both types of exogenous CB ligands. For example, despite the promising efficacy of $\triangle 9$-THC to treat various neurodegenerative disorders (Scotter, Abood, \& Glass, 2010) and oncology (Walsh, Nelson, \& Mahmoud, 2003), its psychoactive side-effects continue to be a deterrent to its treatment of AD, ALS, HD and cancer. So currently, Dronabinol, the international nonproprietary name of $\triangle 9$-THC is used to treat anorexia in people with HIV/AIDS in addition to nausea and vomiting in persons undergoing chemotherapy (Haney et al., 2007). Rimonabant, the synCB antagonist that showed promising efficacy to the treatment of diabetes and was therefore approved by the European 
Union in 2006 was later discontinued from commercial markets and clinical research because of grave risk of psychiatric disorders.

Indeed, natural products paved the way for the current understanding of the ECS and their value in structural diversification, ECS signal transduction pathway elucidation and the synthesis of CB ligands continue to steer future directional ECS research. But the efficacy of both natural and synthetic compounds seems to lie in their specific association with the $\mathrm{CBs}$ and $\mathrm{CB}$ associated targets and their concentration, the latter confirming the theory of Paracelsus. This indeed requires more mechanistic investigations in a systematic way in order to delineate the mode of action of the phyCBs and synCBs. Understanding further, the mechanism used by synthetic versus natural drugs to elicit beneficial effects specifically through the various targets outlined in Fig. 2 is paramount. One such example is the effects of allosterism on the ECS' functionality as was delineated for the synthetic allosteric modulator, ORG27569. ORG27569 enhanced the current selective direct CB agonists, competitive antagonists and enzyme inhibitors. The concept of allosterism to provide an enriched landscape for novel therapeutics is shared by Changeux \& Christopoulos (2016). Further, delineating the $\mathrm{CB}$ conformational states and their desensitization, internalization, resensitization, and downregulation (Raehal \& Bohn, 2014) regulated through the $\beta$ arrestins may be pivotal to advancing the development of $\mathrm{CB}$ exogenous ligands with enhanced efficacy. What is now needed is evidence of the clinical efficacy of $\mathrm{CB}$ induced $\beta$-arrestin modulation that are aligned with the observed efficacy of combination therapies of $\mu O R$ analgesic, morphine and $\mu O R$ antagonists, naloxone and naltrexone, usually given minutes apart. These antagonists diminish $\beta$-arrestin recruitment resulting in the improved analgesic properties of morphine while endowing significantly reduced side-effects caused by morphine, like nausea (Gan et al., 1997; Rebel, Sloan, \& Andrykowski, 2009). The role of $\beta$-arrestin modulation warrants further research in ECS associated disorders and preclinical findings demonstrate the antinociceptive potential of $\triangle 9$-THC in $\beta$-arrestin2-KO mice (Raehal \& Bohn, 2014). Nonetheless, alternatives to treat nausea and vomiting with reduced CNS related side-effects exist like the class of setron (e.g. Ondansetron).

Crystal structures of the CBs are necessary and could assist in identifying more neutral or peripherally exclusive drug leads especially in light of the many drug withdrawals. Given the recent advance in $\mathrm{CB}_{1}$ crystal structure elucidation, advances in further delineating binding associations of the natural and synthetic leads to the CBs will be propelled further, paving the way for maximizing potential synergism within combination therapies. Understanding how the efficacy of one product whether natural or synthetic, impacts another, in that, if it enhances/diminishes bioactivities of other eCBs and exogenous CBs may only be achieved with a more comprehensive overview of the ECS. Even though significant strides have been made in this area, there remains much to be uncovered, for example, other putative CBs like orphan GPR55 and GPR18 receptors that are controlled by cannabinoid like molecules in addition to their participatory role in the ECS (Haugh, Penman, Irving, \& Campbell, 2016). Additionally, there also remains much to be uncovered about the $G$ proteins and the modulatory effects of phyCBs compared to synCBs with respect to the $\mathrm{CB} / \mathrm{G}$ protein complexes. Furthermore, findings suggest that particular $G$ protein mutations are more favorable to bind nonclassical cannabinoid ligands (Shim, Bertalovitz, \& Kendall, 2011) compared to classical ones. G protein modulation seems to hold promise in cancer treatment and possibly prevention (Fan et al., 2013), yet the precise mechanism of action especially in relation to the ECS including which of the numerous subunits under the $G$ protein family are impacted and how, remains unknown. Dated research demonstrates the effects of phyCBs and synCBs on various $G$ protein activation dependent and independent of $\mathrm{CB}$ activation. Overall, the synCB, HU201 was found more potent than the eCB, $\mathrm{AEA}$ and the phyCB, $\triangle 9$-THC (Glass \& Northup, 1999).

Finally, what is needed is a high-throughput systematic mechanism for screening the phyCBs and their analogues and is discussed further in the review article by Zhang and Xie (2012) that readily integrates not only therapeutic signal transduction pathways but also relevant adverse pathways in order to truly ascertain phyCBs that have novel therapeutic actions not mirrored by synthetic drugs. The seven helical scaffolds of the CBs warrant pharmacological assays that can compute biased rejoinders and measured expression in chemical scaffolds to enhance biased effects. Classical in vitro assays are limiting yet efficient while preclinical research findings contribute to clinical translation, although limitations on efficiency and costs continue to be a challenge. Hence, an in vitro method that enables rapid results emblematic of clinical efficacy taking into account age, inflammation, genetic and epigenetic alterations within the CBs and its targets is ideal though a momentous task. Therefore organ-on-chip technology (van der Helm, van der Meer, Eijkel, van den Berg, \& Segerink, 2016) when fully streamlined maybe an ideal route that will propel the development of phyCBs in treating ECS associated morbidities.

\section{Expert opinion by David Puett}

This paper presents a comprehensive and critical timely overview of cannabinoid receptors and the endogenous and exogenous ligands, both synthetic and naturally occurring, that act via $\mathrm{CB}_{1}$ and $\mathrm{CB}_{2}$. These receptors are members of the $G$ protein-coupled receptor (GPCR) superfamily that constitutes the largest gene family in the human genome, indeed with an estimated 800 members and accounting for approximately $1 \%$ of the total protein coding genes. The crystallographic structures of several GPCRs, and most recently the $\mathrm{CB}_{1}$ as well as members of the four families of the associated $G$ proteins, have been elucidated in recent years, thus facilitating detailed structure-function studies. The review of signaling mechanisms presented by the authors and the discussion of endocannabinoids set the stage nicely for the discussion that follows on exogenous synthetic and naturally occurring ligands that hold promise in treating a variety of disorders. The concluding section outlines the importance of research on this topic and offers cogent recommendations for advancement of the field. This paper will make a timely and valuable contribution to the literature.

\section{Conflict of interest}

The authors report no conflict of interest at this time.

\section{Submission declaration}

The authors report that the manuscript is not being considered for publication elsewhere and its publication is approved by all authors.

\section{Funding sources}

S. Badal is supported by the National Health Fund (214163), Jamaica and Principal's New Initiative Fund (15120), UWI, Mona.

The funding sources had no involvement in this work.

\section{Acknowledgments}

The authors would like to acknowledge no one at this time.

\section{References}

Ablat, N., Lv, D., Ren, R., Xiaokaiti, Y., Ma, X., Zhao, X., ... Pu, X. (2016). Neuroprotective effects of a standardized flavonoid extract from safflower against a rotenone-induced rat model of Parkinson's disease. Molecules, 21

Abood, M. E., Rizvi, G., Sallapudi, N., \& McAllister, S. D. (2001). Activation of the CB1 cannabinoid receptor protects cultured mouse spinal neurons against excitotoxicity. Neuroscience Letters 309, 197-201.

Abrams, D. I. (2016). Integrating cannabis into clinical cancer care. Current Oncology 23, S8-S14.

Ahn, K. H., Mahmoud, M. M., \& Kendall, D. A. (2012). Allosteric modulator ORG27569 induces CB1 cannabinoid receptor high affinity agonist binding state, receptor internalization, and Gi protein-independent ERK1/2 kinase activation. The Journal of Biological Chemistry 287, 12070-12082. 
Ahn, K. H., Mahmoud, M. M., Shim, J. Y., \& Kendall, D. A. (2013). Distinct roles of betaarrestin 1 and beta-arrestin 2 in ORG27569-induced biased signaling and internalization of the cannabinoid receptor 1 (CB1). The Journal of Biological Chemistry 288, 9790-9800.

Aizpurua-Olaizola, O., Soydaner, U., Öztürk, E., Schibano, D., Simsir, Y., Navarro, P., ... Usobiaga, A. (2016). Evolution of the cannabinoid and terpene content during the growth of Cannabis sativa plants from different chemotypes. Journal of Natural Products 79, 324-331.

Alberich Jorda, M., Rayman, N., Tas, M., Verbakel, S. E., Battista, N., van Lom, K., ... Delwel, R. (2004). The peripheral cannabinoid receptor $\mathrm{Cb} 2$, frequently expressed on AML blasts, either induces a neutrophilic differentiation block or confers abnormal migration properties in a ligand-dependent manner. Blood 104, 526-534.

Alvarez, F. J., Lafuente, H., Rey-Santano, M. C., Mielgo, V. E., Gastiasoro, E., Rueda, M., .. Martinez-Orgado, J. (2008). Neuroprotective effects of the nonpsychoactive cannabinoid cannabidiol in hypoxic-ischemic newborn piglets. Pediatric Research 64, 653-658.

Amada, N., Yamasaki, Y., Williams, C. M., \& Whalley, B. J. (2013). Cannabidivarin (CBDV) suppresses pentylenetetrazole (PTZ)-induced increases in epilepsy-related gene expression. Peer] 1, e214.

Ameri, A. (1999). The effects of cannabinoids on the brain. Progress in Neurobiology 58 315-348

American Herbal Pharmacopoeia (2013). Botanical pharmacognosy - Microscopic characterization of botanical medicine. CRC Press.

Appendino, G., Gibbons, S., Giana, A., Pagani, A., Grassi, G., Stavri, M., ... Rahman, M. M. (2008). Antibacterial cannabinoids from Cannabis sativa: A structure-activity study. Journal of Natural Products 71, 1427-1430.

Aronne, L. J., Tonstad, S., Moreno, M., Gantz, I., Erondu, N., Suryawanshi, S., ... Amatruda, J. M. (2010). A clinical trial assessing the safety and efficacy of taranabant, a CB1R inverse agonist, in obese and overweight patients: A high-dose study. International Journal of Obesity 34, 919-935.

Asimaki, O., \& Mangoura, D. (2011). Cannabinoid receptor 1 induces a biphasic ERK activation via multiprotein signaling complex formation of proximal kinases PKCepsilon, Src, and Fyn in primary neurons. Neurochemistry International 58, 135-144.

Avraham, Y., Ben-Shushan, D., Breuer, A., Zolotarev, O., Okon, A., Fink, N., ... Berry, E. M. (2004). Very low doses of delta 8-THC increase food consumption and alter neurotransmitter levels following weight loss. Pharmacology, Biochemistry, and Behavior 77, 675-684.

Babitha, P. P., Sahila, M. M., Bandaru, S., Nayarisseri, A., \& Sureshkumar, S. (2015). Molecula docking and pharmacological investigations of rivastigmine-fluoxetine and coumarintacrine hybrids against acetyl choline esterase. Bioinformation 11, 378-386.

Banister, S. D., Moir, M., Stuart, J., Kevin, R. C., Wood, K. E., Longworth, M., ... Kassiou, M. (2015). Pharmacology of indole and indazole synthetic cannabinoid designer drugs AB-FUBINACA, ADB-FUBINACA, AB-PINACA, ADB-PINACA, 5F-AB-PINACA, 5F-ADBPINACA, ADBICA, and 5F-ADBICA. ACS Chemical Neuroscience 6, 1546-1559.

Banni, S., \& Di Marzo, V. (2010). Effect of dietary fat on endocannabinoids and related mediators: Consequences on energy homeostasis, inflammation and mood. Molecula Nutrition \& Food Research 54, 82-92.

Batkai, S., Pacher, P., Jarai, Z., Wagner, J. A., \& Kunos, G. (2004). Cannabinoid antagonist SR 141716 inhibits endotoxic hypotension by a cardiac mechanism not involving CB1 or CB2 receptors. American Journal of Physiology. Heart and Circulatory Physiology 287 H595-H600.

Beal, J. E., Olson, R., Laubenstein, L., Morales, J. O., Bellman, P., Yangco, B., ... Shepard, K. V. (1995). Dronabinol as a treatment for anorexia associated with weight loss in patients with AIDS. Journal of Pain and Symptom Management 10, 89-97.

Berrendero, F. \& Maldonado, R. (2002). Involvement of the opioid system in the anxiolytic-like effects induced by Delta(9)-tetrahydrocannabinol. Psychopharmacology 163 111-117.

Berrendero, F., Romero, J., Garcia-Gil, L., Suarez, I., De la Cruz, P., Ramos, J. A., \& FernandezRuiz, J. J. (1998). Changes in cannabinoid receptor binding and mRNA levels in severa brain regions of aged rats. Biochimica et Biophysica Acta 1407, 205-214.

Bisogno, T., Hanus, L., De Petrocellis, L., Tchilibon, S., Ponde, D. E., Brandi, I., ... Di Marzo, V. (2001). Molecular targets for cannabidiol and its synthetic analogues: Effect on vanilloid VR1 receptors and on the cellular uptake and enzymatic hydrolysis of anandamide. British Journal of Pharmacology 134, 845-852.

Bjenning, C., Al-Shamma, H., Thomsen, W., Leonard, J., \& Behan, D. (2004). G proteincoupled receptors as therapeutic targets for obesity and type 2 diabetes. Current Opinion in Investigational Drugs 5, 1051-1062.

Black, S. C. (2004). Cannabinoid receptor antagonists and obesity. Current Opinion in Investigational Drugs 5, 389-394.

Blankman, J. L., Simon, G. M., \& Cravatt, B. F. (2007). A comprehensive profile of brain enzymes that hydrolyze the endocannabinoid 2-arachidonoylglycerol. Chemistry $\mathcal{E}$ Biology 14, 1347-1356.

Boekholdt, S. M., \& Peters, R. J. (2010). Rimonabant: Obituary for a wonder drug. Lancet 376, 489-490.

Bolognini, D., Costa, B., Maione, S., Comelli, F., Marini, P., Di Marzo, V., ... Pertwee, R. G. (2010) The plant cannabinoid Delta9-tetrahydrocannabivarin can decrease signs of inflammation and inflammatory pain in mice. British Journal of Pharmacology 160, 677-687.

Borrelli, F., Fasolino, I., Romano, B., Capasso, R., Maiello, F., Coppola, D., ... Izzo, A. A. (2013). Beneficial effect of the non-psychotropic plant cannabinoid cannabigerol on experimental inflammatory bowel disease. Biochemical Pharmacology 85, 1306-1316.

Borzelleca, J. F. (2000). Paracelsus: Herald of modern toxicology. Toxicological Sciences 53, $2-4$.

Bosier, B., Muccioli, G. G., Hermans, E., \& Lambert, D. M. (2010). Functionally selective cannabinoid receptor signalling: Therapeutic implications and opportunities. Biochemical Pharmacology 80, 1-12.

Bouaboula, M., Poinot-Chazel, C., Marchand, J., Canat, X., Bourrie, B., RinaldiCarmona, M., ... Casellas, P. (1996). Signaling pathway associated with stimulation of CB2 peripheral cannabinoid receptor. Involvement of both mitogen-activated protein kinase and induction of Krox-24 expression. European Journal of Biochemistry 237, 704-711.

Boyd, S. T., \& Fremming, B. A. (2005). Rimonabant-A selective CB1 antagonist. The Annals of Pharmacotherapy 39, 684-690.

Braida, D., Limonta, V., Malabarba, L., Zani, A., \& Sala, M. (2007a). 5-HT1A receptors are involved in the anxiolytic effect of Delta9-tetrahydrocannabinol and AM 404, the anandamide transport inhibitor, in Sprague-Dawley rats. European Journal of Pharmacology $555,156-163$

Braida, D., Limonta, V., Pegorini, S., Zani, A., Guerini-Rocco, C., Gori, E., \& Sala, M. (2007b). Hallucinatory and rewarding effect of salvinorin A in zebrafish: Kappa-opioid and CB1-cannabinoid receptor involvement. Psychopharmacology 190, 441-448.

Breivogel, C. S., Lambert, J. M., Gerfin, S., Huffman, J. W., \& Razdan, R. K. (2008). Sensitivity to delta9-tetrahydrocannabinol is selectively enhanced in beta-arrestin2 -/- mice. Behavioural Pharmacology 19, 298-307.

Busquets-Garcia, A., Gomis-Gonzalez, M., Guegan, T., Agustin-Pavon, C., Pastor, A., Mato, S., ... Ozaita, A. (2013). Targeting the endocannabinoid system in the treatment of fragile X syndrome. Nature Medicine 19, 603-607.

Cabral, G. A., Ferreira, G. A., \& Jamerson, M. J. (2015). Endocannabinoids and the immune system in health and disease. Handbook of Experimental Pharmacology 231, 185-211.

Cabral, G. A., \& Griffin-Thomas, L. (2009). Emerging role of the cannabinoid receptor CB2 in immune regulation: Therapeutic prospects for neuroinflammation. Expert Reviews in Molecular Medicine 11, e3.

Cabrera-Vera, T. M., Vanhauwe, J., Thomas, T. O., Medkova, M., Preininger, A., Mazzoni, M. R., \& Hamm, H. E. (2003). Insights into G protein structure, function, and regulation. Endocrine Reviews 24, 765-781.

Cadas, H., di Tomaso, E., \& Piomelli, D. (1997). Occurrence and biosynthesis of endogenous cannabinoid precursor, $\mathrm{N}$-arachidonoyl phosphatidylethanolamine, in rat brain. The Journal of Neuroscience 17, 1226-1242.

Capasso, R., Borrelli, F., Aviello, G., Romano, B., Scalisi, C., Capasso, F., \& Izzo, A. A. (2008a). Cannabidiol, extracted from Cannabis sativa, selectively inhibits inflammatory hypermotility in mice. British Journal of Pharmacology 154, 1001-1008.

Capasso, R., Borrelli, F., Cascio, M. G., Aviello, G., Huben, K., Zjawiony, J. K., ... Izzo, A. A. (2008b). Inhibitory effect of salvinorin A, from Salvia divinorum, on ileitis-induced hypermotility: Cross-talk between kappa-opioid and cannabinoid $\mathrm{CB}(1)$ receptors. British Journal of Pharmacology 155, 681-689.

Carai, M. A., Colombo, G., \& Gessa, G. L. (2005). Rimonabant: The first therapeutically relevant cannabinoid antagonist. Life Sciences 77, 2339-2350.

Castillo, A., Tolon, M. R., Fernandez-Ruiz, J., Romero, J., \& Martinez-Orgado, J. (2010). The neuroprotective effect of cannabidiol in an in vitro model of newborn hypoxic-ischemic brain damage in mice is mediated by $\mathrm{CB}(2)$ and adenosine receptors. Neurobiology of Disease 37, 434-440.

Centonze, D., Finazzi-Agro, A, Bernardi, G. \& Maccarrone, M. (2007). The endocannabinoid system in targeting inflammatory neurodegenerative diseases. Trends in Pharmacological Sciences 28, 180-187.

Chakravarti, B., Ravi, J., \& Ganju, R. K. (2014). Cannabinoids as therapeutic agents in cancer: Current status and future implications. Oncotarget 5, 5852-5872.

Changeux, J. P., \& Christopoulos, A. (2016). Allosteric modulation as a unifying mechanism for receptor function and regulation. Cell 166, 1084-1102.

Chen, Y., \& Buck, J. (2000). Cannabinoids protect cells from oxidative cell death: A receptor-independent mechanism. The Journal of Pharmacology and Experimental Therapeutics 293, 807-812.

Chevaleyre, V., Takahashi, K. A., \& Castillo, P. E. (2006). Endocannabinoid-mediated synaptic plasticity in the CNS. Annual Review of Neuroscience 29, 37-76.

Chicca, A., Marazzi, J., \& Gertsch, J. (2012). The antinociceptive triterpene $\beta$-amyrin inhibits 2-arachidonoylglycerol (2-AG) hydrolysis without directly targeting cannabinoid receptors. British Journal of Pharmacology 167, 1596-1608.

Childers, S. R. (2006). Activation of G-proteins in brain by endogenous and exogenous cannabinoids. The AAPS Journal 8, E112-E117.

Chiu, P., Olsen, D. M., Borys, H. K., Karler, R., \& Turkanis, S. A. (1979). The influence of cannabidiol and delta 9-tetrahydrocannabinol on cobalt epilepsy in rats. Epilepsia $20,365-375$

Chorvat, R. J. (2013). Peripherally restricted CB1 receptor blockers. Bioorganic \& Medicinal Chemistry Letters 23, 4751-4760.

Clayton, N., Marshall, F. H., Bountra, C., \& O'Shaughnessy, C. T. (2002). CB1 and CB2 cannabinoid receptors are implicated in inflammatory pain. Pain 96, 253-260.

Colasanti, B. K., Lindamood, C., 3rd, \& Craig, C. R. (1982). Effects of marihuana cannabinoids on seizure activity in cobalt-epileptic rats. Pharmacology, Biochemistry, and Behavior 16, 573-578.

Čolović, M. B., Krstić, D. Z., Lazarević-Pašti, T. D., Bondžić, A. M., \& Vasić, V. M. (2013). Acetylcholinesterase inhibitors: Pharmacology and toxicology. Current Neuropharmacology 11, 315-335.

Conti, S., Costa, B., Colleoni, M., Parolaro, D., \& Giagnoni, G. (2002). Antiinflammatory action of endocannabinoid palmitoylethanolamide and the synthetic cannabinoid nabilone in a model of acute inflammation in the rat. British Journal of Pharmacology 135, 181-187.

Costa, B., Colleoni, M., Conti, S., Parolaro, D., Franke, C., Trovato, A. E., \& Giagnoni, G. (2004). Oral anti-inflammatory activity of cannabidiol, a non-psychoactive constituent of cannabis, in acute carrageenan-induced inflammation in the rat paw. Naunyn-Schmiedeberg's Archives of Pharmacology 369, 294-299.

Cumella, J., Hernandez-Folgado, L., Giron, R., Sanchez, E., Morales, P., Hurst, D. P., ... Jagerovic, N. (2012). Chromenopyrazoles: Non-psychoactive and selective CB(1) cannabinoid agonists with peripheral antinociceptive properties. ChemMedChem 7, 452-463.

Cunha, J. M., Carlini, E. A., Pereira, A. E., Ramos, O. L., Pimentel, C., Gagliardi, R., ... Mechoulam, R. (1980). Chronic administration of cannabidiol to healthy volunteers and epileptic patients. Pharmacology 21, 175-185. 
Dackis, C. A., \& Gold, M. S. (1985). New concepts in cocaine addiction: The dopamine depletion hypothesis. Neuroscience E Biobehavioral Reviews 9, 469-477.

Dahl, S. G., \& Sylte, I. (2005). Molecular modelling of drug targets: The past, the present and the future. Basic \& Clinical Pharmacology \& Toxicology 96, 151-155.

Daigle, T. L., Kearn, C. S., \& Mackie, K. (2008). Rapid CB1 cannabinoid receptor desensitization defines the time course of ERK1/2 MAP kinase signaling. Neuropharmacology $54,36-44$.

Dalton, G. D., Bass, C. E., Van Horn, C., \& Howlett, A. C. (2009). Signal transduction via cannabinoid receptors. CNS \& Neurological Disorders Drug Targets 8, 422-431.

Darmani, N. A., Janoyan, J. J., Crim, J., \& Ramirez, J. (2007). Receptor mechanism and antiemetic activity of structurally diverse cannabinoids against radiation-induced emesis in the Least shrew. European Journal of Pharmacology 563, 187-196.

Darmani, N. A., Sim-Selley, L. J., Martin, B. R., Janoyan, J. J., Crim, J. L., Parekh, B., \& Breivogel, C. S. (2003). Antiemetic and motor-depressive actions of CP55,940: Cannabinoid CB1 receptor characterization, distribution, and G-protein activation. European Journal of Pharmacology 459, 83-95.

Das, M., \& Khanna, S. K. (1997). Clinicoepidemiological, toxicological, and safety evaluation studies on argemone oil. Critical Reviews in Toxicology 27, 273-297.

Davis, M. I., Ronesi, J., \& Lovinger, D. M. (2003). A predominant role for inhibition of the adenylate cyclase/protein kinase A pathway in ERK activation by cannabinoid receptor 1 in N1E-115 neuroblastoma cells. The Journal of Biological Chemistry 278, 48973-48980.

De Filippis, D., Cipriano, M., Esposito, G., Scuderi, C., Steardo, L., \& Iuvone, T. (2010). Are anti-angiogenic drugs useful in neurodegenerative disorders? CNS \& Neurological Disorders Drug Targets 9, 807-812.

De Filippis, D., Russo, A., D'Amico, A., Esposito, G., Pietropaolo, C., Cinelli, M., ... Iuvone, T. (2008). Cannabinoids reduce granuloma-associated angiogenesis in rats by controlling transcription and expression of mast cell protease-5. British Journal of Pharmacology 154, 1672-1679.

Derkinderen, P., Ledent, C., Parmentier, M., \& Girault, J. A. (2001). Cannabinoids activate p38 mitogen-activated protein kinases through CB1 receptors in hippocampus. Journal of Neurochemistry 77, 957-960.

Devane, W. A., Hanus, L., Breuer, A., Pertwee, R. G., Stevenson, L. A., Griffin, G., ... Mechoulam, R. (1992). Isolation and structure of a brain constituent that binds to the cannabinoid receptor. Science 258, 1946-1949.

Dewey, W. L. (1986). Cannabinoid pharmacology. Pharmacological Reviews 38, 151-178.

Dhopeshwarkar, A. S., Jain, S., Liao, C., Ghose, S. K., Bisset, K. M., \& Nicholson, R. A. (2011) The actions of benzophenanthridine alkaloids, piperonyl butoxide and (S)methoprene at the G-protein coupled cannabinoid $\mathrm{CB}(1)$ receptor in vitro. European Journal of Pharmacology 654, 26-32.

Di Marzo, V., \& Despres, J. P. (2009). CB1 antagonists for obesity-What lessons have we learned from rimonabant? Nature Reviews. Endocrinology 5, 633-638.

Di Marzo, V., Fontana, A., Cadas, H., Schinelli, S., Cimino, G., Schwartz, J. C., \& Piomelli, D. (1994). Formation and inactivation of endogenous cannabinoid anandamide in central neurons. Nature 372, 686-691.

Di Marzo, V., \& Maccarrone, M. (2008). FAAH and anandamide: Is 2-AG really the odd one out? Trends in Pharmacological Sciences 29, 229-233.

Di Marzo, V., \& Piscitelli, F. (2015). The endocannabinoid system and its modulation by phytocannabinoids. Neurotherapeutics 12, 692-698.

Di Marzo, V., Stella, N., \& Zimmer, A. (2015). Endocannabinoid signalling and the deteriorating brain. Nature Reviews. Neuroscience 16, 30-42.

Ding, Y., Qiu, Y., Jing, L., Thorn, D. A., Zhang, Y., \& Li, J. X. (2014). Behavioral effects of the cannabinoid CB1 receptor allosteric modulator ORG27569 in rats. Pharmacology Research E Perspectives 2, e00069.

Doggrell, S. A. (2004). New drugs and new targets. Drug News \& Perspectives 17, 615-632.

Dutra, R. C., Simao da Silva, K. A., Bento, A. F., Marcon, R., Paszcuk, A. F., Meotti, F. C., ... Calixto, J. B. (2012). Euphol, a tetracyclic triterpene produces antinociceptive effects in inflammatory and neuropathic pain: The involvement of cannabinoid system. Neuropharmacology 63, 593-605.

El-Remessy, A. B., Khalil, I. E., Matragoon, S., Abou-Mohamed, G., Tsai, N. J., Roon, P., ... Liou, G. I. (2003). Neuroprotective effect of $(-)$ Delta9-tetrahydrocannabinol and cannabidiol in $\mathrm{N}$-methyl-D-aspartate-induced retinal neurotoxicity: Involvement of peroxynitrite. The American Journal of Pathology 163, 1997-2008.

Fan, H., Kotsikorou, E., Hoffman, A. F., Ravert, H. T., Holt, D., Hurst, D. P., ... Horti, A. G. (2009). Analogs of JHU75528, a PET ligand for imaging of cerebral cannabinoid receptors (CB1): Development of ligands with optimized lipophilicity and binding affinity. European Journal of Medicinal Chemistry 44, 593-608.

Fan, Y., Peng, A., He, S., Shao, X., Nie, C., \& Chen, L. (2013). Isogambogenic acid inhibits tumour angiogenesis by suppressing Rho GTPases and vascular endothelial growth factor receptor 2 signalling pathway. Journal of Chemotherapy 25, 298-308.

Feng, Z., Alqarni, M. H., Yang, P., Tong, Q., Chowdhury, A., Wang, L., \& Xie, X. -Q. (2014). Modeling, molecular dynamics simulation, and mutation validation for structure of cannabinoid receptor 2 based on known crystal structures of GPCRs. Journal of Chemical Information and Modeling 54, 2483-2499.

Fernandez-Ruiz, J. (2009). The endocannabinoid system as a target for the treatment of motor dysfunction. British Journal of Pharmacology 156, 1029-1040.

Fernandez-Ruiz, J., Garcia, C., Sagredo, O., Gomez-Ruiz, M., \& de Lago, E. (2010). The endocannabinoid system as a target for the treatment of neuronal damage. Expert Opinion on Therapeutic Targets 14, 387-404.

Fernandez-Ruiz, J., Sagredo, O., Pazos, M. R., Garcia, C., Pertwee, R., Mechoulam, R., \& Martinez-Orgado, J. (2013). Cannabidiol for neurodegenerative disorders: Important new clinical applications for this phytocannabinoid? British Journal of Clinical Pharmacology 75, 323-333.

Fichna, J., Schicho, R., Andrews, C. N., Bashashati, M., Klompus, M., McKay, D. M., ... Storr, M. A. (2009). Salvinorin A inhibits colonic transit and neurogenic ion transport in mice by activating kappa-opioid and cannabinoid receptors. Neurogastroenterology and Motility 21, 1326-e1128.
Filozof, C., Fernandez Pinilla, M. C., \& Fernandez-Cruz, A. (2004). Smoking cessation and weight gain. Obesity Reviews 5, 95-103.

Fish, B. S., Consroe, P., \& Fox, R. R. (1983). Convulsant-anticonvulsant properties of delta9-tetrahydrocannabinol in rabbits. Behavior Genetics 13, 205-211.

Gan, T. J., Ginsberg, B., Glass, P. S., Fortney, J., Jhaveri, R., \& Perno, R. (1997). Opioid-sparing effects of a low-dose infusion of naloxone in patient-administered morphine sulfate. Anesthesiology 87, 1075-1081.

Gaoni, Y., \& Mechoulam, R. (1964). Isolation, structure, and partial synthesis of an active constituent of hashish. Journal of the American Chemical Society 86, 1646-1647.

Garcia, C., Palomo-Garo, C., Garcia-Arencibia, M., Ramos, J., Pertwee, R., \& Fernandez-Ruiz, J. (2011). Symptom-relieving and neuroprotective effects of the phytocannabinoid Delta(9)-THCV in animal models of Parkinson's disease. British Journal of Pharmacology 163, 1495-1506.

Garcia-Arencibia, M., Gonzalez, S., de Lago, E., Ramos, J. A., Mechoulam, R., \& FernandezRuiz, J. (2007). Evaluation of the neuroprotective effect of cannabinoids in a rat model of Parkinson's disease: Importance of antioxidant and cannabinoid receptorindependent properties. Brain Research 1134, 162-170.

Gardner, E. L. (2005). Endocannabinoid signaling system and brain reward: Emphasis on dopamine. Pharmacology, Biochemistry, and Behavior 81, 263-284.

Gawel, K., Labuz, K., Gibula-Bruzda, E., Jenda, M., Marszalek-Grabska, M., Filarowska, J., ... Kotlinska, J. H. (2016). Cholinesterase inhibitors, donepezil and rivastigmine, attenuate spatial memory and cognitive flexibility impairment induced by acute ethanol in the Barnes maze task in rats. Naunyn-Schmiedeberg's Archives of Pharmacology.

Gebremedhin, D., Lange, A. R., Campbell, W. B., Hillard, C. J., \& Harder, D. R. (1999) Cannabinoid CB1 receptor of cat cerebral arterial muscle functions to inhibit Ltype $\mathrm{Ca}^{2+}$ channel current. The American Journal of Physiology 276, H2085-H2093.

Gerdeman, G. L., Ronesi, J., \& Lovinger, D. M. (2002). Postsynaptic endocannabinoid release is critical to long-term depression in the striatum. Nature Neuroscience 5, $446-451$.

Gertsch, J. (2008). Anti-inflammatory cannabinoids in diet: Towards a better understanding of $\mathrm{CB}(2)$ receptor action? Communicative \& Integrative Biology 1, 26-28.

Gertsch, J., Leonti, M., Raduner, S., Racz, I., Chen, J. -Z., Xie, X. -Q., ... Zimmer, A. (2008). Beta-caryophyllene is a dietary cannabinoid. Proceedings of the National Academy of Sciences of the United States of America 105, 9099-9104.

Gertsch, J., Pertwee, R. G., \& Di Marzo, V. (2010). Phytocannabinoids beyond the cannabis plant - Do they exist? British Journal of Pharmacology 160, 523-529.

Gertsch, J., Raduner, S., \& Altmann, K. H. (2006). New natural noncannabinoid ligands for cannabinoid type-2 (CB2) receptors. Journal of Receptor and Signal Transduction Research 26, 709-730.

Gilbert, G. L., Kim, H. J., Waataja, J. J., \& Thayer, S. A. (2007). Delta9-tetrahydrocannabinol protects hippocampal neurons from excitotoxicity. Brain Research 1128, 61-69.

Glass, M., \& Felder, C. C. (1997). Concurrent stimulation of cannabinoid CB1 and dopamine D2 receptors augments cAMP accumulation in striatal neurons: Evidence for a Gs linkage to the CB1 receptor. The Journal of Neuroscience 17, 5327-5333.

Glass, M., \& Northup, J. K. (1999). Agonist selective regulation of G proteins by cannabinoid $\mathrm{CB}(1)$ and $\mathrm{CB}(2)$ receptors. Molecular Pharmacology 56, 1362-1369.

Gomez Del Pulgar, T., De Ceballos, M. L., Guzman, M., \& Velasco, G. (2002). Cannabinoids protect astrocytes from ceramide-induced apoptosis through the phosphatidylinositol 3-kinase/protein kinase B pathway. The Journal of Biological Chemistry 277, 36527-36533.

Gonsiorek, W., Lunn, C., Fan, X., Narula, S., Lundell, D., \& Hipkin, R. W. (2000). Endocannabinoid 2-arachidonyl glycerol is a full agonist through human type 2 cannabinoid receptor: Antagonism by anandamide. Molecular Pharmacology 57, 1045-1050.

Gonzalez-Rosales, F., \& Walsh, D. (1997). Intractable nausea and vomiting due to gastrointestinal mucosal metastases relieved by tetrahydrocannabinol (dronabinol). Journa of Pain and Symptom Management 14, 311-314.

Granja, A. G., Carrillo-Salinas, F., Pagani, A., Gomez-Canas, M., Negri, R., Navarrete, C., ... Munoz, E. (2012). A cannabigerol quinone alleviates neuroinflammation in a chronic model of multiple sclerosis. Journal of Neuroimmune Pharmacology 7, 1002-1016.

Griffin, G., Fernando, S. R., Ross, R. A., McKay, N. G., Ashford, M. L., Shire, D., ... Pertwee, R. G. (1997). Evidence for the presence of CB2-like cannabinoid receptors on peripheral nerve terminals. European Journal of Pharmacology 339, 53-61.

Grlic, L. (1976). A comparative study on some chemical and biological characteristics of various samples of cannabis resin. Bulletin on Narcotics 14, 37-46.

Guhring, H., Schuster, J., Hamza, M., Ates, M., Kotalla, C. E., \& Brune, K. (2001). HU-210 shows higher efficacy and potency than morphine after intrathecal administration in the mouse formalin test. European Journal of Pharmacology 429, 127-134.

Guindon, J., \& Hohmann, A. G. (2008). Cannabinoid CB2 receptors: A therapeutic target for the treatment of inflammatory and neuropathic pain. British Journal of Pharmacology $153,319-334$

Guindon, J., \& Hohmann, A. G. (2011). The endocannabinoid system and cancer: Therapeutic implication. British Journal of Pharmacology 163, 1447-1463.

Guiotto, P., Woelkart, K., Grabnar, I., Voinovich, D., Perissutti, B., Invernizzi, S., ... Bauer, R. (2008). Pharmacokinetics and immunomodulatory effects of phytotherapeutic lozenges (bonbons) with Echinacea purpurea extract. Phytomedicine 15, 547-554.

Guzman, M. (2003). Cannabinoids: Potential anticancer agents. Nature Reviews. Cancer 3 , 745-755.

Gyombolai, P., Toth, A. D., Timar, D., Turu, G., \& Hunyady, L. (2015). Mutations in the 'DRY motif of the CB1 cannabinoid receptor result in biased receptor variants. Journal of Molecular Endocrinology 54, 75-89.

Haney, M., Gunderson, E. W., Rabkin, J., Hart, C. L., Vosburg, S. K., Comer, S. D., \& Foltin, R. W. (2007). Dronabinol and marijuana in HIV-positive marijuana smokers. Caloric intake, mood, and sleep. Journal of Acquired Immune Deficiency Syndromes $45,545-554$. 
Hanuš, L., Breuer, A., Tchilibon, S., Shiloah, S., Goldenberg, D., Horowitz, M., ... Fride, E. (1999). HU-308: A specific agonist for $\mathrm{CB}(2)$, a peripheral cannabinoid receptor. Proceedings of the National Academy of Sciences of the United States of America 96, $14228-14233$.

Hassanzadeh, P., \& Hassanzadeh, A. (2012). The CB(1) receptor-mediated endocannabinoid signaling and NGF: The novel targets of curcumin. Neurochemical Research 37, 1112-1120.

Haugh, O., Penman, J., Irving, A. J., \& Campbell, V. A. (2016). The emerging role of the cannabinoid receptor family in peripheral and neuro-immune interactions. Current Drug Targets

Hazekamp, A., \& Grotenhermen, F. (2010). Review on clinical studies with cannabis and cannabinoids 2005-2009. Cannabinoids 5, 1-21.

Hegde, V. L., Nagarkatti, M., \& Nagarkatti, P. S. (2010). Cannabinoid receptor activation leads to massive mobilization of myeloid-derived suppressor cells with potent immunosuppressive properties. European Journal of Immunology 40, 3358-3371.

van der Helm, M. W., van der Meer, A. D., Eijkel, J. C., van den Berg, A., \& Segerink, L. I. (2016). Microfluidic organ-on-chip technology for blood-brain barrier research. Tissue Barriers 4, e1142493.

Herzberg, U., Eliav, E., Bennett, G. J., \& Kopin, I. J. (1997). The analgesic effects of R(+) WIN 55,212-2 mesylate, a high affinity cannabinoid agonist, in a rat model of neuropathic pain. Neuroscience Letters 221, 157-160.

Hiebel, C., Kromm, T. Stark, M., \& Behl, C. (2014). Cannabinoid receptor 1 modulates the autophagic flux independent of mTOR- and BECLIN1-complex. Journal of Neurochemistry 131, 484-497.

Hilairet, S., Bouaboula, M., Carriere, D., Le Fur, G., \& Casellas, P. (2003). Hypersensitization of the orexin 1 receptor by the $\mathrm{CB} 1$ receptor: Evidence for cross-talk blocked by the specific CB1 antagonist, SR141716. The Journal of Biological Chemistry 278, 23731-23737.

Hill, T. D., Cascio, M. G., Romano, B., Duncan, M., Pertwee, R. G., Williams, C. M., ... Hill, A. J. (2013). Cannabidivarin-rich cannabis extracts are anticonvulsant in mouse and rat via a CB1 receptor-independent mechanism. British Journal of Pharmacology 170 679-692.

Hill, A. J., Weston, S. E., Jones, N. A., Smith, I., Bevan, S. A., Williamson, E. M., ... Whalley, B. J. (2010). Delta(9)-Tetrahydrocannabivarin suppresses in vitro epileptiform and in vivo seizure activity in adult rats. Epilepsia $51,1522-1532$.

Hill, A. J., Williams, C. M., Whalley, B. J., \& Stephens, G. J. (2012). Phytocannabinoids as novel therapeutic agents in CNS disorders. Pharmacology \& Therapeutics 133 , 79-97.

Howlett, A. C., Barth, F., Bonner, T. I., Cabral, G., Casellas, P., Devane, W. A., ... Pertwee, R. G. (2002). International Union of Pharmacology. XXVII. Classification of cannabinoid receptors. Pharmacological Reviews 54, 161-202.

Howlett, A. C., Breivogel, C. S., Childers, S. R., Deadwyler, S. A., Hampson, R. E., \& Porrino, L J. (2004). Cannabinoid physiology and pharmacology: 30 years of progress Neuropharmacology 47(Suppl. 1), 345-358.

Howlett, A., \& Shim, J. Y. (2000-2013). Cannabinoid receptors and signal transduction. Landes Bioscience.

Howlett, A. C., Song, C., Berglund, B. A., Wilken, G. H., \& Pigg, J. J. (1998). Characterization of CB1 cannabinoid receptors using receptor peptide fragments and site-directed antibodies. Molecular Pharmacology 53, 504-510.

$\mathrm{Hu}, \mathrm{S}$. S. (2016). Involvement of TRPV1 in the olfactory bulb in Rimonabant-induced olfactory discrimination deficit. The Chinese Journal of Physiology 59, 21-32.

Hua, T., Vemuri, K., Pu, M., Qu, L., Han, G. W., Wu, Y., ... Liu, Z. J. (2016). Crystal structure of the human cannabinoid receptor CB1. Cell 167 (750-762.e714).

Iannotti, F. A., Hill, C. L., Leo, A., Alhusaini, A., Soubrane, C., Mazzarella, E., ... Stephens, G. J. (2014). Nonpsychotropic plant cannabinoids, cannabidivarin (CBDV) and cannabidiol (CBD), activate and desensitize transient receptor potential vanilloid 1 (TRPV1) channels in vitro: Potential for the treatment of neuronal hyperexcitability. ACS Chemical Neuroscience 5, 1131-1141.

Insel, P. A., Tang, C. M., Hahntow, I., \& Michel, M. C. (2007). Impact of GPCRs in clinical medicine: Monogenic diseases, genetic variants and drug targets. Biochimica et Biophysica Acta 1768, 994-1005.

Izzo, A. A., Capasso, R., Aviello, G., Borrelli, F., Romano, B., Piscitelli, F., ... Di Marzo, V. (2012). Inhibitory effect of cannabichromene, a major non-psychotropic cannabinoid extracted from Cannabis sativa, on inflammation-induced hypermotility in mice. British Journal of Pharmacology 166, 1444-1460.

Jafari, M. R., Ghiasvand, F., Golmohammadi, S., Zarrindast, M. R., \& Djahanguiri, B. (2008). Influence of central nicotinic receptors on arachidonylcyclopropylamide (ACPA)induced antinociception in mice. The International Journal of Neuroscience 118 531-543.

Jin, W., Brown, S., Roche, J. P., Hsieh, C., Celver, J. P., Kovoor, A., ... Mackie, K. (1999). Distinct domains of the CB1 cannabinoid receptor mediate desensitization and internalization. The Journal of Neuroscience 19, 3773-3780.

Johns, D. G., Behm, D. J., Walker, D. J., Ao, Z., Shapland, E. M., Daniels, D. A., ... Douglas, S. A. (2007). The novel endocannabinoid receptor GPR55 is activated by atypical cannabinoids but does not mediate their vasodilator effects. British Journal of Pharmacology $152,825-831$

Jourdan, T., Szanda, G., Rosenberg, A. Z., Tam, J., Earley, B. J., Godlewski, G., ... Kunos, G. (2014). Overactive cannabinoid 1 receptor in podocytes drives type 2 diabetic nephropathy. Proceedings of the National Academy of Sciences of the United States of America 111, E5420-E5428

Kaczocha, M., Glaser, S. T., \& Deutsch, D. G. (2009). Identification of intracellular carriers for the endocannabinoid anandamide. Proceedings of the National Academy of Sciences of the United States of America 106, 6375-6380.

Kaczocha, M., Rebecchi, M. J., Ralph, B. P., Teng, Y. H., Berger, W. T., Galbavy, W., ... Ojima, I. (2014). Inhibition of fatty acid binding proteins elevates brain anandamide levels and produces analgesia. PloS One 9, e94200.
Karsak, M., Cohen-Solal, M., Freudenberg, J., Ostertag, A., Morieux, C., Kornak, U., ... Zimmer, A. (2005). Cannabinoid receptor type 2 gene is associated with human osteoporosis. Human Molecular Genetics 14, 3389-3396.

Kearn, C. S., Blake-Palmer, K., Daniel, E., Mackie, K., \& Glass, M. (2005). Concurrent stimulation of cannabinoid CB1 and dopamine D2 receptors enhances heterodimer formation: A mechanism for receptor cross-talk? Molecular Pharmacology 67, 1697-1704.

Kenakin, T., \& Miller, L. J. (2010). Seven transmembrane receptors as shapeshifting proteins: The impact of allosteric modulation and functional selectivity on new drug discovery. Pharmacological Reviews 62, 265-304.

King, A. R., Dotsey, E. Y., Lodola, A., Jung, K. M., Ghomian, A., Qiu, Y., ... Piomelli, D. (2009). Discovery of potent and reversible monoacylglycerol lipase inhibitors. Chemistry $\mathcal{E}^{\circ}$ Biology 16, 1045-1052.

Kooti, W., Farokhipour, M., Asadzadeh, Z., Ashtary-Larky, D., \& Asadi-Samani, M. (2016). The role of medicinal plants in the treatment of diabetes: A systematic review. Electronic Physician 8, 1832-1842.

Korte, G., Dreiseitel, A., Schreier, P., Oehme, A., Locher, S., Geiger, S., ... Sand, P. G. (2010). Tea catechins' affinity for human cannabinoid receptors. Phytomedicine 17, 19-22.

Korte, G., Dreiseitel, A., Schreier, P., Oehme, A., Locher, S., Hajak, G., \& Sand, P. G. (2009). An examination of anthocyanins' and anthocyanidins' affinity for cannabinoid receptors. Journal of Medicinal Food 12, 1407-1410.

Kozak, K. R., Crews, B. C., Morrow, J. D., Wang, L. H., Ma, Y. H., Weinander, R., ... Marnett, L. J. (2002). Metabolism of the endocannabinoids, 2-arachidonylglycerol and anandamide, into prostaglandin, thromboxane, and prostacyclin glycerol esters and ethanolamides. The Journal of Biological Chemistry 277, 44877-44885.

Kreitzer, A. C. (2005). Neurotransmission: Emerging roles of endocannabinoids. Current Biology 15, R549-R551.

Kroeze, W. K., Sheffler, D. J., \& Roth, B. L. (2003). G-protein-coupled receptors at a glance. Journal of Cell Science 116, 4867-4869.

Lafuente, H., Alvarez, F. J., Pazos, M. R., Alvarez, A., Rey-Santano, M. C., Mielgo, V., .. Martinez-Orgado, J. (2011). Cannabidiol reduces brain damage and improves functional recovery after acute hypoxia-ischemia in newborn pigs. Pediatric Research 70, 272-277.

Lallemand, F., \& De Witte, P. (2006). SR147778, a CB1 cannabinoid receptor antagonist, suppresses ethanol preference in chronically alcoholized Wistar rats. Alcohol 39, $125-134$

Lamota, L., Bermudez-Silva, F. J., Marco, E. M., Llorente, R., Gallego, A., Rodriguez de Fonseca, F., \& Viveros, M. P. (2008). Effects of adolescent nicotine and SR 147778 (Surinabant) administration on food intake, somatic growth and metabolic parameters in rats. Neuropharmacology 54, 194-205.

Lange, J. H. M., \& Kruse, C. G. (2005). Keynote review: Medicinal chemistry strategies to CB1 cannabinoid receptor antagonists. Drug Discovery Today 10, 693-702.

Lastres-Becker, I., Molina-Holgado, F., Ramos, J. A., Mechoulam, R., \& Fernandez-Ruiz, J. (2005). Cannabinoids provide neuroprotection against 6-hydroxydopamine toxicity in vivo and in vitro: Relevance to Parkinson's disease. Neurobiology of Disease 19, 96-107.

Lauckner, J. E., Hille, B., \& Mackie, K. (2005). The cannabinoid agonist WIN55,212-2 increases intracellular calcium via $\mathrm{CB}(1)$ receptor coupling to $\mathrm{G}(\mathrm{q} / 11) \mathrm{G}$ proteins. Proceedings of the National Academy of Sciences of the United States of America 102, 19144-19149.

Lax, P., Esquiva, G., Altavilla, C., \& Cuenca, N. (2014). Neuroprotective effects of the cannabinoid agonist HU210 on retinal degeneration. Experimental Eye Research 120, 175-185.

Ligresti, A., Moriello, A. S., Starowicz, K., Matias, I., Pisanti, S., De Petrocellis, L., ... Di Marzo, V. (2006). Antitumor activity of plant cannabinoids with emphasis on the effect of cannabidiol on human breast carcinoma. The Journal of Pharmacology and Experimental Therapeutics 318, 1375-1387.

Lim, G., Sung, B., Ji, R. R., \& Mao, J. (2003). Upregulation of spinal cannabinoid-1-receptors following nerve injury enhances the effects of Win 55,212-2 on neuropathic pain behaviors in rats. Pain 105, 275-283.

Liou, G. I., Auchampach, J. A., Hillard, C. J., Zhu, G., Yousufzai, B., Mian, S., ... Khalifa, Y. (2008). Mediation of cannabidiol anti-inflammation in the retina by equilibrative nucleoside transporter and A2A adenosine receptor. Investigative Ophthalmology \& Visual Science 49, 5526-5531.

Lipina, C., Vaanholt, L. M., Davidova, A., Mitchell, S. E., Storey-Gordon, E., Hambly, C., ... Hundal, H. S. (2016). CB1 receptor blockade counters age-induced insulin resistance and metabolic dysfunction. Aging Cell 15, 325-335.

Little, P. J., Compton, D. R., Johnson, M. R., Melvin, L. S., \& Martin, B. R. (1988). Pharmacology and stereoselectivity of structurally novel cannabinoids in mice. The Journal of Pharmacology and Experimental Therapeutics 247, 1046-1051.

Liu, J., Gao, B., Mirshahi, F., Sanyal, A. J., Khanolkar, A. D., Makriyannis, A., \& Kunos, G. (2000). Functional CB1 cannabinoid receptors in human vascular endothelial cells. The Biochemical Journal 346(Pt 3), 835-840.

Liu, H., Patel, R. Y., \& Doerksen, R. J. (2014). Structure of the cannabinoid receptor 1: Homology modeling of its inactive state and enrichment study based on CB1 antagonist docking. Medicinal Chemical Communications 5, 1297-1302.

Lombard, C., Nagarkatti, M., \& Nagarkatti, P. (2007). CB2 cannabinoid receptor agonist, JWH-015, triggers apoptosis in immune cells: Potential role for CB2-selective ligands as immunosuppressive agents. Clinical Immunology 122, 259-270.

Long, L. E., Lind, J., Webster, M., \& Weickert, C. S. (2012). Developmental trajectory of the endocannabinoid system in human dorsolateral prefrontal cortex. BMC Neuroscience 13,87

Lu, D., Dopart, R., \& Kendall, D. A. (2016). Controlled downregulation of the cannabinoid CB1 receptor provides a promising approach for the treatment of obesity and obesity-derived type 2 diabetes. Cell Stress \& Chaperones 21, 1-7.

Lunn, C. A., Fine, J. S., Rojas-Triana, A., Jackson, J. V., Fan, X., Kung, T. T., ... Bober, L. A. (2006). A novel cannabinoid peripheral cannabinoid receptor-selective inverse agonist blocks leukocyte recruitment in vivo. The Journal of Pharmacology and Experimental Therapeutics 316, 780-788. 
Maccarrone, M. (2009). Endocannabinoids: Friends and foes of reproduction. Progress in Lipid Research 48, 344-354.

Maccarrone, M., Bab, I., Biro, T., Cabral, G. A., Dey, S. K., Di Marzo, V., ... Zimmer, A. (2015). Endocannabinoid signaling at the periphery: 50 years after THC. Trends in Pharmacological Sciences 36, 277-296.

Maccarrone, M., Bari, M., Lorenzon, T., Bisogno, T., Di Marzo, V., \& Finazzi-Agro, A. (2000). Anandamide uptake by human endothelial cells and its regulation by nitric oxide. The Journal of Biological Chemistry 275, 13484-13492.

Maccarrone, M., Bernardi, G., Agrò, A. F., \& Centonze, D. (2011). Cannabinoid receptor signalling in neurodegenerative diseases: A potential role for membrane fluidity disturbance. British Journal of Pharmacology 163, 1379-1390.

Maccarrone, M., Valensise, H., Bari, M., Lazzarin, N., Romanini, C., \& Finazzi-Agro, A. (2001) Progesterone up-regulates anandamide hydrolase in human lymphocytes: Role of cytokines and implications for fertility. Journal of Immunology 166, 7183-7189.

Mackie, K., \& Hille, B. (1992). Cannabinoids inhibit N-type calcium channels in neuroblastoma-glioma cells. Proceedings of the National Academy of Sciences of the United States of America 89, 3825-3829.

Mackie, K., Lai, Y., Westenbroek, R., \& Mitchell, R. (1995). Cannabinoids activate an inwardly rectifying potassium conductance and inhibit Q-type calcium currents in AtT20 cells transfected with rat brain cannabinoid receptor. The Journal of Neuroscience 15, 6552-6561.

MacLennan, S., Reynen, P., Kwan, J., Bonhaus, D., \& Martin, G. (1998). [35S]GTPyS binding to assess inverse agonist actions of ligands at human recombinant CB1 and CB2 receptors. Symposium on the cannabinoids (pp. 7). Burlington, Vermont, US: International Cannabinoid Research Society.

Maione, S., Piscitelli, F., Gatta, L., Vita, D., De Petrocellis, L., Palazzo, E., ... Di Marzo, V. (2011). Non-psychoactive cannabinoids modulate the descending pathway of antinociception in anaesthetized rats through several mechanisms of action. British Journal of Pharmacology 162, 584-596.

Marchalant, Y., Rosi, S., \& Wenk, G. L. (2007). Anti-inflammatory property of the cannabinoid agonist WIN-55212-2 in a rodent model of chronic brain inflammation. Neuroscience 144, 1516-1522.

Marco, E. M., Rapino, C., Caprioli, A., Borsini, F., Laviola, G., \& Maccarrone, M. (2015). Potential therapeutic value of a novel FAAH inhibitor for the treatment of anxiety. PloS One 10, e0137034.

Maresz, K., Pryce, G., Ponomarev, E. D., Marsicano, G., Croxford, J. L., Shriver, L. P., ... Dittel, B. N. (2007). Direct suppression of CNS autoimmune inflammation via the cannabinoid receptor CB1 on neurons and CB2 on autoreactive T cells. Nature Medicine 13, 492-497.

Marini, P., Moriello, A. S., Cristino, L., Palmery, M., De Petrocellis, L., \& Di Marzo, V. (2009). Cannabinoid CB1 receptor elevation of intracellular calcium in neuroblastoma SHSY5Y cells: Interactions with muscarinic and $\delta$-opioid receptors. Biochimica et Biophysica Acta (BBA) - Molecular Cell Research 1793, 1289-1303.

Marrs, W. R., Blankman, J. L., Horne, E. A., Thomazeau, A., Lin, Y. H., Coy, J., ... Stella, N. (2010). The serine hydrolase ABHD6 controls the accumulation and efficacy of $2-$ AG at cannabinoid receptors. Nature Neuroscience 13, 951-957.

Martin-Moreno, A. M., Reigada, D., Ramirez, B. G., Mechoulam, R., Innamorato, N., Cuadrado, A., \& de Ceballos, M. L. (2011). Cannabidiol and other cannabinoids reduce microglial activation in vitro and in vivo: Relevance to Alzheimer's disease. Molecular Pharmacology 79, 964-973.

Massi, P., Valenti, M., Vaccani, A., Gasperi, V., Perletti, G., Marras, E., ... Parolaro, D. (2008). 5 Lipoxygenase and anandamide hydrolase (FAAH) mediate the antitumor activity of cannabidiol, a non-psychoactive cannabinoid. Journal of Neurochemistry 104, 1091-1100.

Matsuda, L. A., Lolait, S. J., Brownstein, M. J., Young, A. C., \& Bonner, T. I. (1990). Structure of a cannabinoid receptor and functional expression of the cloned cDNA. Nature 346, 561-564.

McAllister, S. D., Christian, R. T., Horowitz, M. P., Garcia, A., \& Desprez, P. Y. (2007). Cannabidiol as a novel inhibitor of Id-1 gene expression in aggressive breast cancer cells. Molecular Cancer Therapeutics 6, 2921-2927.

McAllister, S. D., Rizvi, G., Anavi-Goffer, S., Hurst, D. P., Barnett-Norris, J., Lynch, D. L., .. Abood, M. E. (2003). An aromatic microdomain at the cannabinoid CB(1) receptor constitutes an agonist/inverse agonist binding region. Journal of Medicinal Chemistry 46, 5139-5152.

McAllister, S. D., Soroceanu, L., \& Desprez, P. Y. (2015). The antitumor activity of plant-derived non-psychoactive cannabinoids. Journal of Neuroimmune Pharmacology 10 255-267.

McLaughlin, P. J., Winston, K., Swezey, L., Wisniecki, A., Aberman, J., Tardif, D. J., .. Salamone, J. D. (2003). The cannabinoid CB1 antagonists SR 141716A and AM 251 suppress food intake and food-reinforced behavior in a variety of tasks in rats. Behavioural Pharmacology 14, 583-588

Mechoulam, R., Ben-Shabat, S., Hanus, L., Ligumsky, M., Kaminski, N. E., Schatz, A. R. Gopher, A., Almog, S., Martin, B. R., Compton, D. R., et al. (1995). Identification of an endogenous 2-monoglyceride, present in canine gut, that binds to cannabinoid receptors. Biochemical Pharmacology 50, 83-90.

Mechoulam, R., Braun, P., \& Gaoni, Y. (1967). A stereospecific synthesis of (-)-delta 1and (-)-delta 1(6)-tetrahydrocannabinols. Journal of the American Chemical Society $89,4552-4554$

Mechoulam, R., Parker, L. A., \& Gallily, R. (2002). Cannabidiol: An overview of some pharmacological aspects. Journal of Clinical Pharmacology 42, 11s-19s.

Medina-Franco, J. L., Giulianotti, M. A., Welmaker, G. S., \& Houghten, R. A. (2013). Shifting from the single to the multitarget paradigm in drug discovery. Drug Discovery Today 18, 495-501.

Meier, B. P., \& Lappas, C. M. (2015). The influence of safety, efficacy, and medical condition severity on natural v. synthetic drug preference. Medical Decision Making.

Melvin, L. S., Milne, G. M., Johnson, M. R., Subramaniam, B., Wilken, G. H., \& Howlett, A. C. (1993). Structure-activity relationships for cannabinoid receptor-binding and analgesic ctivity: Studies of bicyclic cannabinoid analogs. Molecular Pharmacology 44 1008-1015.

Mitscher, L. A., Park, Y. H., Clark, D., Clark, G. W., 3rd, Hammesfahr, P. D., Wu, W. N., \& Beal, J. L. (1978). Antimicrobial agents from higher plants. An investigation of Hunnemannia fumariaefolia pseudoalcoholates of sanguinarine and chelerythrine. Lloydia 41, 145-150.

Muccioli, G. G. (2010). Endocannabinoid biosynthesis and inactivation, from simple to complex. Drug Discovery Today 15, 474-483.

Muccioli, G. G., \& Lambert, D. M. (2005). Current knowledge on the antagonists and inverse agonists of cannabinoid receptors. Current Medicinal Chemistry 12, 1361-1394

Mukhopadhyay, S., Cowsik, S. M., Lynn, A. M., Welsh, W. J., \& Howlett, A. C. (1999). Regulation of $\mathrm{Gi}$ by the $\mathrm{CB} 1$ cannabinoid receptor $\mathrm{C}$-terminal juxtamembrane region: Structural requirements determined by peptide analysis. Biochemistry 38, 3447-3455

Munro, S., Thomas, K. L., \& Abu-Shaar, M. (1993). Molecular characterization of a peripheral receptor for cannabinoids. Nature 365, 61-65.

Murillo-Rodriguez, E., Millan-Aldaco, D., Palomero-Rivero, M., Mechoulam, R., \& DruckerColin, R. (2006). Cannabidiol, a constituent of Cannabis sativa, modulates sleep in rats. FEBS Letters 580, 4337-4345.

Nagai, H., Egashira, N., Sano, K., Ogata, A., Mizuki, A., Mishima, K., ... Fujiwara, M. (2006) Antipsychotics improve Delta9-tetrahydrocannabinol-induced impairment of the prepulse inhibition of the startle reflex in mice. Pharmacology, Biochemistry, and Behavior 84, 330-336.

Newman, D. J., \& Cragg, G. M. (2012). Natural products as sources of new drugs over the 30 years from 1981 to 2010. Journal of Natural Products 75, 311-335.

Nguyen, P. T., Schmid, C. L., Raehal, K. M., Selley, D. E., Bohn, L. M., \& Sim-Selley, L. J. (2012). beta-Arrestin2 regulates cannabinoid CB1 receptor signaling and adaptation in a central nervous system region-dependent manner. Biological Psychiatry 71, 714-724.

Nicolussi, S., Viveros-Paredes, J. M., Gachet, M. S., Rau, M., Flores-Soto, M. E., Blunder, M., \& Gertsch, J. (2014). Guineensine is a novel inhibitor of endocannabinoid uptake showing cannabimimetic behavioral effects in BALB/c mice. Pharmacological Research 80 52-65.

Novack, G. D. (2016). Cannabinoids for treatment of glaucoma. Current Opinion in Ophthalmology 27, 146-150.

Oddi, S., Fezza, F., Pasquariello, N., D'Agostino, A., Catanzaro, G., De Simone, C., ... Maccarrone, M. (2009). Molecular identification of albumin and Hsp70 as cytosolic anandamide-binding proteins. Chemistry \& Biology 16, 624-632.

Ortega-Gutierrez, S., \& Lopez-Rodriguez, M. L. (2005). CB1 and CB2 cannabinoid receptor binding studies based on modeling and mutagenesis approaches. Mini Reviews in Medicinal Chemistry 5, 651-658.

Osei-Hyiaman, D., DePetrillo, M., Pacher, P., Liu, J., Radaeva, S., Batkai, S., ... Kunos, C. (2005). Endocannabinoid activation at hepatic CB1 receptors stimulates fatty acid synthesis and contributes to diet-induced obesity. The Journal of Clinical Investigation 115, 1298-1305.

Overton, H. A., Babbs, A. J., Doel, S. M., Fyfe, M. C., Gardner, L. S., Griffin, G., ... Reynet, C. (2006). Deorphanization of a G protein-coupled receptor for oleoylethanolamide and its use in the discovery of small-molecule hypophagic agents. Cell Metabolism 3, 167-175.

Pacher, P., Batkai, S., \& Kunos, G. (2006). The endocannabinoid system as an emerging target of pharmacotherapy. Pharmacological Reviews 58, 389-462.

Paronis, C. A., Nikas, S. P., Shukla, V. G., \& Makriyannis, A. (2012). delta(9)-Tetrahydrocannabinol acts as a partial agonist/antagonist in mice. Behavioural Pharmacology 23, 802-805.

Patel, S., \& Hillard, C. J. (2006). Pharmacological evaluation of cannabinoid receptor ligands in a mouse model of anxiety: Further evidence for an anxiolytic role for endogenous cannabinoid signaling. The Journal of Pharmacology and Experimental Therapeutics 318, 304-311.

Patel, K., Jain, A., \& Patel, D. K. (2013). Medicinal significance, pharmacological activities, and analytical aspects of anthocyanidins 'delphinidin': A concise report. Journal of Acute Disease 2, 169-178.

Patel, P. N., \& Pathak, R. (2007). Rimonabant: A novel selective cannabinoid-1 receptor antagonist for treatment of obesity. American Journal of Health-System Pharmacy 64 481-489.

Pereira, A., Pfeifer, T. A., Grigliatti, T. A., \& Andersen, R. J. (2009). Functional cell-based screening and saturation transfer double-difference NMR have identified haplosamate A as a cannabinoid receptor agonist. ACS Chemical Biology 4, 139-144.

Pertwee, R. G. (2000). Neuropharmacology and therapeutic potential of cannabinoids. Addiction Biology 5, 37-46.

Pertwee, R. G. (2005). Pharmacological actions of cannabinoids. Handbook of Experimental Pharmacology, 1-51.

Pertwee, R. G. (2006a). Cannabinoid pharmacology: The first 66 years. British Journal of Pharmacology 147(Suppl. 1), S163-S171.

Pertwee, R. G. (2006b). The pharmacology of cannabinoid receptors and their ligands: An overview. International Journal of Obesity 30, S13-S18.

Pertwee, R. G. (2008). The diverse $\mathrm{CB}(1)$ and $\mathrm{CB}(2)$ receptor pharmacology of three plant cannabinoids: $\Delta(9)$-tetrahydrocannabinol, cannabidiol and $\Delta(9)$ tetrahydrocannabivarin. British Journal of Pharmacology 153, 199-215.

Pertwee, R. G. (2009). Emerging strategies for exploiting cannabinoid receptor agonists as medicines. British Journal of Pharmacology 156, 397-411.

Pertwee, R. G., \& Ross, R. A. (2002). Cannabinoid receptors and their ligands. Prostaglandins, Leukotrienes, and Essential Fatty Acids 66, 101-121.

Petitet, F., Jeantaud, B., Reibaud, M., Imperato, A., \& Dubroeucq, M. C. (1998). Complex pharmacology of natural cannabinoids: Evidence for partial agonist activity of delta9-tetrahydrocannabinol and antagonist activity of cannabidiol on rat brain cannabinoid receptors. Life Sciences 63, Pl1-Pl6.

Pfizer (2008). In F. Pharma (Ed.), Pfizer discontinues development program for its phase 3 obesity compound (CP-945,598). Vol. 2016. 
Pharmacodia (2008). Taranabant Taranabant Vol. 2016.

Picardi, P., Ciaglia, E., Proto, M., \& Pisanti, S. (2014). Anandamide inhibits breast tumor-induced angiogenesis. Translational Medicine @UniSa 10, 8-12.

Piiper, A., Stryjek-Kaminska, D., Klengel, R., \& Zeuzem, S. (1997). Epidermal growth factor inhibits bombesin-induced activation of phospholipase C-beta1 in rat pancreatic acinar cells. Gastroenterology 113, 1747-1755.

Pisanu, A., Acquas, E., Fenu, S., \& Di Chiara, G. (2006). Modulation of Delta(9)-THC-induced increase of cortical and hippocampal acetylcholine release by micro opioid and D(1) dopamine receptors. Neuropharmacology 50, 661-670.

Pistis, M., Ferraro, L., Pira, L., Flore, G., Tanganelli, S., Gessa, G. L., \& Devoto, P. (2002) Delta(9)-tetrahydrocannabinol decreases extracellular GABA and increases extracellular glutamate and dopamine levels in the rat prefrontal cortex: An in vivo microdialysis study. Brain Research 948, 155-158.

Portier, M., Rinaldi-Carmona, M., Pecceu, F., Combes, T., Poinot-Chazel, C., Calandra, B., .. Casellas, P. (1999). SR 144528, an antagonist for the peripheral cannabinoid receptor that behaves as an inverse agonist. The Journal of Pharmacology and Experimental Therapeutics 288, 582-589.

Price, M. R., Baillie, G. L., Thomas, A., Stevenson, L. A., Easson, M., Goodwin, R., ... Ross, R. A (2005). Allosteric modulation of the cannabinoid CB1 receptor. Molecular Pharmacology 68, 1484-1495.

Pugh, G., Mason, D. J., Combs, V., \& Welch, S. P. (1997). Involvement of Dynorphin B in the antinociceptive effects of the cannabinoid CP55,940 in the spinal cord. Journal of Pharmacology and Experimental Therapeutics 281, 730-737.

Qiao, C. J., Ali, H. I., Ahn, K. H., Kolluru, S., Kendall, D. A., \& Lu, D. (2016). Synthesis and biological evaluation of indole-2-carboxamides bearing photoactivatable functionalities as novel allosteric modulators for the cannabinoid CB1 receptor. European Journal of Medicinal Chemistry 121, 517-529.

R \& D Focus Drug News (2008). In H. Business (Ed.), Surinabant Sanofi-Aventis discontinued. Sanofi-Aventis S.A stop its clinical trial. Vol. 2016.

Raduner, S., Majewska, A., Chen, J. Z., Xie, X. Q., Hamon, J., Faller, B., ... Gertsch, J. (2006) Alkylamides from Echinacea are a new class of cannabinomimetics. Cannabinoid type 2 receptor-dependent and -independent immunomodulatory effects. The Journal of Biological Chemistry 281, 14192-14206.

Raehal, K. M., \& Bohn, L. M. (2014). Beta-arrestins: Regulatory role and therapeutic potential in opioid and cannabinoid receptor-mediated analgesia. Handbook of Experimental Pharmacology 219, 427-443.

Rahn, E. J., \& Hohmann, A. G. (2009). Cannabinoids as pharmacotherapies for neuropathic pain: From the bench to the bedside. Neurotherapeutics 6, 713-737.

Ranieri, R., Laezza, C., Bifulco, M., Marasco, D., \& Malfitano, A. M. (2016). Endocannabinoid system in neurological disorders. Recent Patents on CNS Drug Discovery 10, 90-112.

Rebel, A., Sloan, P., \& Andrykowski, M. (2009). Postoperative analgesia after radical prostatectomy with high-dose intrathecal morphine and intravenous naloxone: A retrospective review. Journal of Opioid Management 5, 331-339.

Refolo, M. G., D'Alessandro, R., Malerba, N., Laezza, C., Bifulco, M., Messa, C., ... Tutino, V. (2015). Anti proliferative and pro apoptotic effects of flavonoid quercetin are mediated by CB1 receptor in human colon cancer cell lines. Journal of Cellular Physiology 230, 2973-2980.

Reuter, S. E., \& Martin, J. H. (2016). Pharmacokinetics of cannabis in cancer cachexia-anorexia syndrome. Clinical Pharmacokinetics.

Rhee, M. H., Bayewitch, M., Avidor-Reiss, T., Levy, R., \& Vogel, Z. (1998). Cannabinoid receptor activation differentially regulates the various adenylyl cyclase isozymes. Journal of Neurochemistry 71, 1525-1534.

Rinaldi-Carmona, M., Barth, F., Heaulme, M., Shire, D., Calandra, B., Congy, C., Martinez, S., Maruani, J., Neliat, G., Caput, D., et al. (1994). SR141716A, a potent and selective antagonist of the brain cannabinoid receptor. FEBS Letters 350, 240-244.

Rinaldi-Carmona, M., Barth, F., Millan, J., Derocq, J. M., Casellas, P., Congy, C., ... Le Fur, G. L. (1998). SR 144528, the first potent and selective antagonist of the CB2 cannabinoid receptor. The Journal of Pharmacology and Experimental Therapeutics $284,644-650$.

Rinaldi-Carmona, M., Pialot, F., Congy, C., Redon, E., Barth, F., Bachy, A., ... Le Fur, G. (1996). Characterization and distribution of binding sites for [3H]-SR 141716A, a selective brain (CB1) cannabinoid receptor antagonist, in rodent brain. Life Sciences 58, 1239-1247.

Rini, B. I., \& Atkins, M. B. (2009). Resistance to targeted therapy in renal-cell carcinoma The Lancet Oncology 10, 992-1000.

Rodriguez de Fonseca, F., Ramos, J. A., Bonnin, A., \& Fernandez-Ruiz, J. J. (1993). Presence of cannabinoid binding sites in the brain from early postnatal ages. Neuroreport 4 , $135-138$.

Roos, P. H., \& Bolt, H. M. (2005). Cytochrome P450 interactions in human cancers: New aspects considering CYP1B1. Expert Opinion on Drug Metabolism E Toxicology 1, 187-202.

Rosati, O., Messina, F., Pelosi, A., Curini, M., Petrucci, V., Gertsch, J., \& Chicca, A. (2014) One-pot heterogeneous synthesis of delta(3)-tetrahydrocannabinol analogues and xanthenes showing differential binding to $\mathrm{CB}(1)$ and $\mathrm{CB}(2)$ receptors. European Journal of Medicinal Chemistry 85, 77-86.

Ross, R. A., Brockie, H. C., Stevenson, L. A., Murphy, V. L., Templeton, F., Makriyannis, A., \& Pertwee, R. G. (1999). Agonist-inverse agonist characterization at CB1 and CB2 cannabinoid receptors of L759633, L759656, and AM630. British Journal of Pharmacology 126, 665-672.

Rubinsztein, D. C., Marino, G., \& Kroemer, G. (2011). Autophagy and aging. Cell 146 682-695.

Rueda, D., Galve-Roperh, I., Haro, A., \& Guzman, M. (2000). The CB(1) cannabinoid receptor is coupled to the activation of c-Jun N-terminal kinase. Molecular Pharmacology $58,814-820$.
Russo, E. B. (2008). Cannabinoids in the management of difficult to treat pain. Therapeutics and Clinical Risk Management 4, 245-259.

Russo, E. B. (2011). Taming THC: Potential cannabis synergy and phytocannabinoid-terpenoid entourage effects. British Journal of Pharmacology 163, 1344-1364.

Russo, E. B., Burnett, A., Hall, B., \& Parker, K. K. (2005). Agonistic properties of cannabidiol at 5-HT1a receptors. Neurochemical Research 30, 1037-1043.

Rutkowska, M., \& Fereniec-Goltbiewska, L. (2006). ACEA (arachidonyl-2chloroethylamide), the selective cannabinoid CB1 receptor agonist, protects against aspirin-induced gastric ulceration. Pharmazie 61, 341-342.

Sagredo, O., Gonzalez, S., Aroyo, I., Pazos, M. R., Benito, C., Lastres-Becker, I., ... FernandezRuiz, J. (2009). Cannabinoid CB2 receptor agonists protect the striatum against malonate toxicity: Relevance for Huntington's disease. Glia 57, 1154-1167.

Sagredo, O., Pazos, M. R., Satta, V., Ramos, J. A., Pertwee, R. G., \& Fernandez-Ruiz, J. (2011). Neuroprotective effects of phytocannabinoid-based medicines in experimental models of Huntington's disease. Journal of Neuroscience Research 89, 1509-1518.

Sagredo, O., Ramos, J. A., Decio, A., Mechoulam, R., \& Fernandez-Ruiz, J. (2007). Cannabidiol reduced the striatal atrophy caused 3-nitropropionic acid in vivo by mechanisms independent of the activation of cannabinoid, vanilloid TRPV1 and adenosine A2A receptors. The European Journal of Neuroscience 26, 843-851.

Sanchez, C., de Ceballos, M. L., Gomez del Pulgar, T., Rueda, D., Corbacho, C., Velasco, G., ... Ramon y Cajal, S., \& Guzman, M. (2001). Inhibition of glioma growth in vivo by selective activation of the $\mathrm{CB}(2)$ cannabinoid receptor. Cancer Research 61, 5784-5789.

Sanofi-aventis (2008). Sanofi-aventis to discontinue all clinical trials with rimonabant Vol. 2016.

dos Santos, R. G., Hallak, J. E., Leite, J. P., Zuardi, A. W., \& Crippa, J. A. (2015). Phytocannabinoids and epilepsy. Journal of Clinical Pharmacy and Therapeutics 40, 135-143.

Sathyapalan, T., Dakroury, Y., Ahmed, L., Elshewehy, A. M., Kilpatrick, E. S., Coady, A. M., \& Atkin, S. L. (2016). Endocannabinoid receptor blockade increases hepatocyte growth factor and reduces insulin levels in obese women with polycystic ovary syndrome. Clinical Endocrinology.

Savinainen, J. R., Saario, S. M., \& Laitinen, J. T. (2012). The serine hydrolases MAGL, ABHD6 and ABHD12 as guardians of 2-arachidonoylglycerol signalling through cannabinoid receptors. Acta Physiologica (Oxford, England) 204, 267-276.

Schindler, C. W., Redhi, G. H., Vemuri, K., Makriyannis, A., Le Foll, B., Bergman, J., ... Justinova, Z. (2016). Blockade of nicotine and cannabinoid reinforcement and relapse by a cannabinoid CB1-receptor neutral antagonist AM4113 and inverse agonist Rimonabant in squirrel monkeys. Neuropsychopharmacology 41, 2283-2293.

Schmid, P. C., Reddy, P. V., Natarajan, V., \& Schmid, H. H. (1983). Metabolism of Nacylethanolamine phospholipids by a mammalian phosphodiesterase of the phospholipase D type. The Journal of Biological Chemistry 258, 9302-9306.

Schramm-Sapyta, N. L., Cha, Y. M., Chaudhry, S., Wilson, W. A., Swartzwelder, H. S., \& Kuhn, C. M. (2007). Differential anxiogenic, aversive, and locomotor effects of THC in adolescent and adult rats. Psychopharmacology 191, 867-877.

Scotter, E. L., Abood, M. E., \& Glass, M. (2010). The endocannabinoid system as a target for the treatment of neurodegenerative disease. British Journal of Pharmacology 160, 480-498.

Seely, K. A. Levi, M. S. \& Prather, P. L. (2009). The dietary polyphenols trans-resveratrol and curcumin selectively bind human CB1 cannabinoid receptors with nanomolar affinities and function as antagonists/inverse agonists. The Journal of Pharmacology and Experimental Therapeutics 330, 31-39.

Sekiguchi, Y., Zhang, J., Patterson, S., Liu, L., Hamada, C., Tomino, Y., \& Margetts, P. J. (2012). Rapamycin inhibits transforming growth factor beta-induced peritoneal angiogenesis by blocking the secondary hypoxic response. Journal of Cellular and Molecular Medicine 16, 1934-1945.

Shao, Z., Yin, J., Chapman, K., Grzemska, M., Clark, L., Wang, J., \& Rosenbaum, D. M. (2016). High-resolution crystal structure of the human CB1 cannabinoid receptor. Nature 540, 602-606.

Sharma, C., Al Kaabi, J. M., Nurulain, S. M., Goyal, S. N., Kamal, M. A., \& Ojha, S. (2016). Polypharmacological properties and therapeutic potential of beta-caryophyllene: A dietary phytocannabinoid of pharmaceutical promise. Current Pharmaceutical Design 22, 3237-3264

Sharma, C., Sadek, B., Goyal, S. N., Sinha, S., \& Kamal, M. A. (2015). Small molecules from nature targeting G-protein coupled cannabinoid receptors: Potential leads for drug discovery and development2015, 238482

Shearman, L. P., Rosko, K. M., Fleischer, R., Wang, J., Xu, S., Tong, X. S., \& Rocha, B. A. (2003). Antidepressant-like and anorectic effects of the cannabinoid CB1 receptor inverse agonist AM251 in mice. Behavioural Pharmacology 14, 573-582.

Sherman, B. J., \& McRae-Clark, A. L. (2016). Treatment of cannabis use disorder: Current science and future outlook. Pharmacotherapy.

Shim, J. -Y., Bertalovitz, A. C., \& Kendall, D. A. (2011). Identification of essential cannabinoid-binding domains: Structural insights into early dynamic events in receptor activation. The Journal of Biological Chemistry 286, 33422-33435.

Shim, J. Y., Welsh, W. J., \& Howlett, A. C. (2003). Homology model of the CB1 cannabinoid receptor: Sites critical for nonclassical cannabinoid agonist interaction. Biopolymers $71,169-189$

Showalter, V. M., Compton, D. R., Martin, B. R., \& Abood, M. E. (1996). Evaluation of binding in a transfected cell line expressing a peripheral cannabinoid receptor (CB2): Identification of cannabinoid receptor subtype selective ligands. The Journal of Pharmacology and Experimental Therapeutics 278, 989-999.

da Silva, K. A., Paszcuk, A. F., Passos, G. F., Silva, E. S., Bento, A. F., Meotti, F. C., \& Calixto, J. B. (2011). Activation of cannabinoid receptors by the pentacyclic triterpene alpha,betaamyrin inhibits inflammatory and neuropathic persistent pain in mice. Pain 152 , 1872-1887. 
Sim, L. J., Hampson, R. E., Deadwyler, S. A., \& Childers, S. R. (1996). Effects of chronic treatment with delta9-tetrahydrocannabinol on cannabinoid-stimulated [35S]GTPgammaS autoradiography in rat brain. The Journal of Neuroscience 16, 8057-8066.

Skaper, S. D., \& Walsh, F. S. (1998). Neurotrophic molecules: Strategies for designing effective therapeutic molecules in neurodegeneration. Molecular and Cellular Neurosciences 12, 179-193.

Sofia, R. D., Vassar, H. B., \& Knobloch, L. C. (1975). Comparative analgesic activity of various naturally occurring cannabinoids in mice and rats. Psychopharmacologia 40, 285-295.

Soria-Gomez, E., Bellocchio, L., \& Marsicano, G. (2014). New insights on food intake control by olfactory processes: The emerging role of the endocannabinoid system. Molecular and Cellular Endocrinology 397, 59-66.

Stefano, G. B., Salzet, B., Rialas, C. M., Pope, M., Kustka, A., Neenan, K., ... Salzet, M. (1997). Morphine- and anandamide-stimulated nitric oxide production inhibits presynaptic dopamine release. Brain Research 763, 63-68.

Stella, N. (2010). Cannabinoid and cannabinoid-like receptors in microglia, astrocytes, and astrocytomas. Glia 58, 1017-1030.

van der Stelt, M., Veldhuis, W. B., Bar, P. R., Veldink, G. A., Vliegenthart, J. F., \& Nicolay, K. (2001). Neuroprotection by delta9-tetrahydrocannabinol, the main active compound in marijuana, against ouabain-induced in vivo excitotoxicity. The Journal of Neuroscience 21, 6475-6479.

Sugiura, T., Kondo, S., Sukagawa, A., Nakane, S., Shinoda, A., Itoh, K., ... Waku, K. (1995). 2 Arachidonoylglycerol: A possible endogenous cannabinoid receptor ligand in brain. Biochemical and Biophysical Research Communications 215, 89-97.

Sun, M., Lou, W., Chun, J. Y., Cho, D. S., Nadiminty, N., Evans, C. P., ... Gao, A. C. (2010). Sanguinarine suppresses prostate tumor growth and inhibits survivin expression. Genes \&' Cancer 1, 283-292.

Svíženská, I., Dubový, P., \& Šulcová, A. (2008). Cannabinoid receptors 1 and 2 (CB1 and CB2), their distribution, ligands and functional involvement in nervous system structures - A short review. Pharmacology Biochemistry and Behavior 90, 501-511.

Thomas, A., Baillie, G. L., Phillips, A. M., Razdan, R. K., Ross, R. A., \& Pertwee, R. G. (2007). Cannabidiol displays unexpectedly high potency as an antagonist of CB1 and CB2 receptor agonists in vitro. British Journal of Pharmacology 150, 613-623.

Thomas, H., Ze-Jun, W., Edward, A. B., \& Paul, T. A. (2016). Endocannabinoid signaling in neural circuits of the olfactory and limbic system, cannabinoids in health and disease. InTech.

Tourino, C., Zimmer, A., \& Valverde, O. (2010). THC prevents MDMA neurotoxicity in mice. PloS One 5, e9143.

Trezza, V., \& Campolongo, P. (2013). The endocannabinoid system as a possible target to treat both the cognitive and emotional features of post-traumatic stress disorder (PTSD). Frontiers in Behavioral Neuroscience 7, 100.

Turkanis, S. A., \& Karler, R. (1981). Electrophysiologic properties of the cannabinoids. Journal of Clinical Pharmacology 21, 449s-463s.

Valdeolivas, S., Navarrete, C., Cantarero, I., Bellido, M. L., Munoz, E., \& Sagredo, O. (2015). Neuroprotective properties of cannabigerol in Huntington's disease: Studies in R6/2 mice and 3-nitropropionate-lesioned mice. Neurotherapeutics 12, 185-199.

Vaseghi, G., Rabbani, M., \& Hajhashemi, V. (2012). The CB(1) receptor antagonist, AM281, improves recognition loss induced by naloxone in morphine withdrawal mice. Basic E' Clinical Pharmacology \& Toxicology 111, 161-165.

Vaughan, C. W., \& Christie, M. J. (2005). Retrograde signalling by endocannabinoids. Handbook of Experimental Pharmacology, 367-383.

Velasco, G., Sanchez, C., \& Guzman, M. (2016). Anticancer mechanisms of cannabinoids. Current Oncology 23, S23-S32.
Vemuri, V. K., Janero, D. R., \& Makriyannis, A. (2008). Pharmacotherapeutic targeting of the endocannabinoid signaling system: Drugs for obesity and the metabolic syndrome. Physiology \& Behavior 93, 671-686.

Wallace, M. J., Blair, R. E., Falenski, K. W., Martin, B. R., \& DeLorenzo, R. J. (2003). The endogenous cannabinoid system regulates seizure frequency and duration in a model of temporal lobe epilepsy. The Journal of Pharmacology and Experimental Therapeutics 307, 129-137.

Walsh, D., Nelson, K. A., \& Mahmoud, F. A. (2003). Established and potential therapeutic applications of cannabinoids in oncology. Support Care Cancer 11, 137-143.

Walter, L., Franklin, A., Witting, A., Wade, C., Xie, Y., Kunos, G., ... Stella, N. (2003). Nonpsychotropic cannabinoid receptors regulate microglial cell migration. The Journal of Neuroscience 23, 1398-1405.

Wang, L., Liu, J., Harvey-White, J., Zimmer, A., \& Kunos, G. (2003). Endocannabinoid signaling via cannabinoid receptor 1 is involved in ethanol preference and its age-dependent decline in mice. Proceedings of the National Academy of Sciences of the United States of America 100, 1393-1398.

Wang, N., Shen, X., Bao, S., Feng, S. W., Wang, W., Liu, Y., ... Wang, F. (2016a). Dopaminergic inhibition by G9a/Glp complex on tyrosine hydroxylase in nerve injury-induced hypersensitivity. Molecular Pain 12.

Wang, X., Zhang, C., Wang, Y., Hu, W., Shao, X., Zhang, J. G., \& Zhang, K. (2016b). Prognostic factors for seizure outcome in patients with MRI-negative temporal lobe epilepsy: A meta-analysis and systematic review. Seizure 38, 54-62.

Wartmann, M., Campbell, D., Subramanian, A., Burstein, S. H., \& Davis, R. J. (1995). The MAP kinase signal transduction pathway is activated by the endogenous cannabinoid anandamide. FEBS Letters 359, 133-136.

Webster, G. R., \& Sarna, L. (2007). Cb-delta8-Thc composition. In: Google Patents.

Weissman, A., Milne, G. M., \& Melvin, L. S., Jr. (1982). Cannabimimetic activity from CP47,497, a derivative of 3-phenylcyclohexanol. The Journal of Pharmacology and Experimental Therapeutics 223, 516-523.

Wilson, R. I., \& Nicoll, R. A. (2002). Endocannabinoid signaling in the brain. Science 296, 678-682.

Yang, X., Solomon, S., Fraser, L. R., Trombino, A. F., Liu, D., Sonenshein, G. E., ... Sherr, D. H. (2008). Constitutive regulation of CYP1B1 by the aryl hydrocarbon receptor (AhR) in pre-malignant and malignant mammary tissue. Journal of Cellular Biochemistry 104, $402-417$.

Zachary, I. (1998). Vascular endothelial growth factor. The International Journal of Biochemistry \& Cell Biology 30, 1169-1174.

Zani, A., Braida, D., Capurro, V., \& Sala, M. (2007). delta9-Tetrahydrocannabinol (THC) and AM 404 protect against cerebral ischaemia in gerbils through a mechanism involving cannabinoid and opioid receptors. British Journal of Pharmacology 152, 1301-1311.

Zhang, R., \& Xie, X. (2012). Tools for GPCR drug discovery. Acta Pharmacologica Sinica 33, 372-384.

Zheng, L., Wu, X., Dong, X., Ding, X., \& Song, C. (2015). Effects of chronic alcohol exposure on the modulation of ischemia-induced glutamate release via cannabinoid receptors in the dorsal hippocampus. Alcoholism, Clinical and Experimental Research 39 1908-1916.

Zimmer, C., Treschan, T. A., Meier, S., \& Nosch, M. (2009). Long-term treatment with oral ketamine. Case report of a female patient with therapy-resistant post-herpetic neuralgia. Schmerz 23, 525-527.

Zlebnik, N. E., \& Cheer, J. F. (2016). Beyond the CB1 receptor: Is cannabidiol the answer for disorders of motivation? Annual Review of Neuroscience. 